\title{
Parasites of cartilaginous fishes (Chondrichthyes) in South Africa - a neglected field of marine science
}

\author{
Bjoern C. Schaeffner and Nico J. Smit
}

Water Research Group, Unit for Environmental Sciences and Management, Potchefstroom Campus, North-West University, Potchefstroom, South Africa

\begin{abstract}
Southern Africa is considered one of the world's 'hotspots' for the diversity of cartilaginous fishes (Chondrichthyes), with currently 204 reported species. Although numerous literature records and treatises on chondrichthyan fishes are available, a paucity of information exists on the biodiversity of their parasites. Chondrichthyan fishes are parasitised by several groups of protozoan and metazoan organisms that live either permanently or temporarily on and within their hosts. Reports of parasites infecting elasmobranchs and holocephalans in South Africa are sparse and information on most parasitic groups is fragmentary or entirely lacking. Parasitic copepods constitute the best-studied group with currently 70 described species (excluding undescribed species or nomina nuda) from chondrichthyans. Given the large number of chondrichthyan species present in southern Africa, it is expected that only a mere fraction of the parasite diversity has been discovered to date and numerous species await discovery and description. This review summarises information on all groups of parasites of chondrichthyan hosts and demonstrates the current knowledge of chondrichthyan parasites in South Africa. Checklists are provided displaying the host-parasite and parasite-host data known to date.
\end{abstract}

Keywords: Elasmobranchii, Holocephali, diversity, host-parasite list, parasite-host list

The biogeographical realm of Temperate Southern Africa (sensu Spalding et al. 2007) is dominated by two major ocean currents - the Benguela Current and the Agulhas Current - separating the realm in two distinct marine provinces, the Benguela and Agulhas provinces (sensu Spalding et al. 2007), respectively. The Agulhas province comprises the eastern and most of the southern coastline of South Africa. The marine waters of this province are subject to the warm, fast-flowing Agulhas Current, running southward from the equatorial Indian Ocean along the East-African coastline towards Cape Point (Briggs 1995, Van As et al. 2012). The Benguela province encompasses the marine environment of Namibia and the western coastline of South Africa in the south-eastern Atlantic Ocean. This province is influenced by the cold and slow-flowing Benguela Current, flowing northwards from the Antarctic towards Angola (Briggs 1995). The Temperate Southern African realm exhibits a rich ichthyofauna (Heemstra and Heemstra 2004, Branch et al. 2016, Nelson et al. 2016).

The marine environment of southern Africa is considered one of the most biodiverse regions for chondrichthyan fishes on this planet (Ebert and van Hees 2015, Weigmann, 2016). Chondrichthyans are cartilaginous fishes, uniting the elasmobranchs (i.e. modern sharks and rays) and holocephalans (i.e. chimaeras). The first treatise for the identification of cartilaginous fishes in southern Africa (Com- pagno et al. 1989) listed a total of 171 species (i.e. 100 sharks [S], 64 rays [R], seven chimaeras [C]). Since then, the number of known species increased and new species discoveries in this charismatic group are frequent. Two recent studies on the chondrichthyan fauna of southern Africa reported c. 210 (i.e. 118 S, 82 R, 10 C; Compagno 1999) and c. 204 (i.e. 119 S, 79 R, 8 C; Ebert and van Hees 2015) species of chondrichthyans. This vast diversity of species accounts for roughly $17 \%$ of all chondrichthyans known worldwide (Ebert and van Hees 2015).

The level of endemicity is relatively high, with c. 13\% of species restricted to the waters of southern Africa (Ebert and van Hees 2015). Interestingly, the fauna is not equally distributed (Compagno 1999, Ebert and van Hees 2015) and the geographical distribution of most chondrichthyans is limited to either biogeographical province (Ebert and van Hees 2015). The chondrichthyan fauna in the warmer Agulhas province is significantly more diverse, with 175 predominantly tropical and warm-temperate species (Ebert and van Hees 2015). In contrast, the chondrichthyan fauna of the Benguela province in the south-eastern Atlantic consists of only 96 temperate species (Ebert and van Hees 2015). A smaller proportion of chondrichthyan species share an extended distribution over both biogeographical provinces (i.e. 62 species; Ebert and van Hees 2015).

Address for correspondence: B. C. Schaeffner, Water Research Group, Unit for Environmental Sciences and Management, Potchefstroom Campus, North-West University, J.S. van der Merwe building (E6), 11 Hoffman Street, Potchefstroom, 2531, South Africa. Phone: +27 (18) 299 2367; E-mail: bjorn.schaffner@nwu.ac.za 
At present, the diversity, biogeography and biology of cartilaginous fishes in southern Africa is reasonably well documented. However, very little is known about their parasites. In South Africa, marine parasitology has a long history, dating back about 200 years, since Leach (1818) described the first parasitic organism, a fish parasitic isopod, Anilocra capensis Leach, 1818 (Crustacea: Isopoda), from Cape Town (see Smit and Hadfield 2015). Until now, numerous parasite species have been described, predominantly from teleost fishes (e.g. Fantham 1918, Barnard 1955a, Kensley and Grindley 1973, Kensley 1978, Bray 1984, 1985, 1986, 1987, 1990, 1991, Oldewage 1992a, 1993a, Oldewage and Avenant-Oldewage 1993, Oldewage and Smale 1993, Dippenaar 2004). Only a minor proportion of the marine parasite diversity of South Africa has been explored and taxonomic groups that are covered by experts are limited (Griffiths et al. 2010).

Parasitic copepods represent the best-studied and documented group (e.g. Barnard 1955a, Kensley and Grindley 1973, Oldewage and Avenant-Oldewage 1993, Oldewage and Smale 1993, Dippenaar 2004, 2009, Dippenaar and Jordaan 2007, Dippenaar et al. 2010), mainly due to the personal preferences and expertise of a small number of aquatic parasitologists working in this region. Other parasitic groups (e.g. Annelida, Myxozoa, Platyhelminthes, parasitic protists), especially from poorly-studied hosts (i.e. certain elasmobranch families), are in need of taxonomic evaluation.

Chondrichthyans host a wide range of parasitic organisms (Cheung 1993, Benz and Bullard 2004, Caira et al. 2012). However, relatively few parasite species are documented from this host group in South Africa. To our knowledge, not a single, large-scale systematic survey on the parasite fauna of cartilaginous fishes from South Africa has been undertaken and reports of individual parasite species are based solely on opportunistic findings. The first parasite recorded from a chondrichthyan host in South Africa was a fluke (Digenea) detected in the body cavity of an unidentified species of catshark (Scyliorhinidae) from the southeastern Atlantic off Cape Town (see von Ofenheim 1900). Specimens described by von Ofenheim (1900) were obtained from the Natural History Museum in Berlin and were considered conspecific with Probolitrema richiardii (López, 1888), a species described earlier from the Mediterranean Sea (von Ofenheim 1900).

The current knowledge of the parasite fauna of chondrichthyans from South Africa is dominated by parasitic copepods. Although few scientists dedicated much of their scientific career to the exploration of parasitic copepods, only a fraction of potential chondrichthyan hosts have been investigated and the species currently known from South Africa might represent only the 'tip of the iceberg'. The second largest group of parasites reported from this host group are tapeworms (Cestoda). However, information on this group of internal parasites is based on just nine independent studies.

In a recent report on parasites of elasmobranchs, Caira et al. (2012) stated that the cestode diversity "exceeds that of all of the other metazoan groups parasitising elas- mobranchs combined". On a global scale, ten out of the 19 known orders of cestodes infect chondrichthyans, with a total of 1,044 species most cestodes parasitise elasmobranchs as definitive hosts (Caira and Jensen 2017). Relatively few cestodes are found in holocephalans; one of the smallest cestode orders, the Gyrocotylidea with a total of 10 species, and certain members of the Phyllobothriidea (Caira and Jensen 2017). The most recent estimate on the global diversity of cestodes infecting elasmobranchs is 5,126 species (see Caira and Jensen 2017). With 1,269 species of elasmobranchs currently known worldwide, this represents an average of four cestode species per elasmobranch host (Caira and Jensen 2017).

Although cestodes currently constitute the second largest group of known chondrichthyan parasites in South Africa, merely 18 of 204 potential host species have been examined for cestode infections. We assume that the diversity of cestodes in South Africa is at least equal to, if not larger than, the diversity of chondrichthyan hosts. Predicting the number of cestodes infecting chondrichthyans in South Africa would be purely hypothetical. However, it is clear that a potentially large proportion of the actual diversity still remains to be discovered. The remaining parasitic groups known to infect chondrichthyans are very poorly explored. Overall, a total of 19 species of six parasite groups (i.e. trypanosomes, ciliates, monogeneans, trematodes, nematodes and isopods) were reported from South Africa. Information on the remaining 12 groups (i.e. amoebae, sporozoans, myxozoans, planarians, acanthocephalans, hirudineans, gastropods, mites, ostracods, amphipods, brachiurans and barnacles) is entirely absent.

The aim of this study is to provide an overview of parasite infection of elasmobranchs and holocephalans and comprehensive information on the current knowledge from South Africa. In addition, parasite-host and host-parasite checklists are provided for the first time, summarising records of chondrichthyan and parasite species, their classification and the respective literature.

\section{PARASITE GROUPS INFECTING CHONDRICH- THYANS}

\section{Trypanosomes (Protozoa, Eozoa, Euglenozoa, \\ Kinetoplastea, Trypanosomatida)}

On a global scale, only relatively few trypanosomes have been reported from chondrichthyan hosts (Burreson 1989, Aragort et al. 2005, Davies et al. 2012). The first trypanosome species from this host group in South Africa was reported by Fantham (1918), who found an unidentified species of Trypanosoma Gruby, 1843 in the onefin electric ray, Narke capensis (Gmelin) (Narkidae), which until now remains undescribed.

Almost 90 years later, Yeld and Smit (2006) reported a second trypanosome species, Trypanosoma haploblephari Yeld et Smit, 2006, from the peripheral blood of two endemic species of catsharks, Haploblepharus pictus (Müller et Henle) and Haploblepharus edwardsii (Schinz), with a prevalence of $100 \%$ of 143 specimens examined. Infection by trypanosomes is greatly increased with sedentary, bot- 
tom-dwelling hosts in colder climates (Khan et al. 1980). The known host spectrum of trypanosomes recorded from chondrichthyan hosts is comprised of elasmobranchs, predominantly of the families Rajidae and Scyliorhinidae, but also Hemiscylliidae, Dasyatidae, Torpedinidae, Narkidae, Odontaspididae and Rhinobatidae. Holocephalans were thus far not reported to host trypanosomes. The mode of transmission of marine fish trypanosomes involves piscicolid leeches as vectors (Karlsbakk 2004, Hayes et al. 2014).

\section{Amoebae (Protozoa, Sarcomastigophora, Amoebozoa)}

Although mostly considered free-living organsims, a few parasitic amoebae infect fishes (Rohde 2005). These organisms cause amoebiasis in their teleost hosts, which manifests in lesions to external surfaces (i.e. gills, skin) and rarely the intestine. Chondrichthyan infections are insignificant and have been rarely reported (Cheung 1993, Goertz 2004, Garner 2013). If chondrichthyan individuals are infected, it is mostly associated with necrosis and hemorrhage of liver and brain tissues.

\section{Ciliates (Chromista, Harosa, Ciliophora)}

Trichodinid ciliophorans are a poorly studied group of parasites that most commonly occur on the gills and skin of teleosts in freshwater and marine environments (Lom 1970, Lom and Dyková 1992, Van As and Basson 1996, Xu et al. 2001). Several species were also reported as endosymbionts occurring in the urinary system and intestinal tract of fishes (Mueller 1932, Basson et al. 1990). Very few studies (Evdokimova et al. 1969, Khan 1972, Van As and Basson 1996) reported species of Trichodina Ehrenberg, 1830 from the oviducts, genital and urinary systems of rajid and rhinobatid hosts.

The only species known from cartilaginous fishes in South Africa was described by Van As and Basson (1996). Trichodina rhinobatae Van As et Basson, 1996 was found in the urogenital tract of Acroteriobatus annulatus (Müller et Henle) (Rhinobatidae) collected at the mouth of the Olifants River in the Western Cape Province. Van As and Basson (1996) assumed transmission could be linked to the reproductive behaviour of the elasmobranch hosts, since a number of trichodinid endosymbionts were also encountered on external gill filaments of embryos in utero (Van As and Basson 1996).

Coccidians (Chromista, Harosa, Myzozoa, Apicomplexa, Sporozoa, Conoidasida, Coccidiasina)

Coccidians are apicomplexan parasites of vertebrate and invertebrate hosts, with direct and indirect transmission strategies (Davies and Ball 1993). Xavier et al. (2018) suggested that coccidians follow the evolution of their hosts, with basal lineages infecting chondrichthyans, while more derived lineages are found in higher vertebrates. Although numerous species of coccidians are known to infect fishes, their diversity remains poorly explored (Molnár et al. 2012). Reports of coccidians from chondrichthyan hosts are sparse. Most coccidians reported from this host group belong to the speciose genus Eimeria Schneider, 1875
(Eimeriidae) (e.g. Dyková and Lom 1981, Lom and Dyková 1981, 1992), whereas the genus Goussia Labbé, 1896 (Eimeriidae) contains only a single species (Lom and Dyková 1981). Additional coccidian blood parasites known to infect chondrichthyans are species of Haemogregarina Danilewsky, 1885 (Haemogregarinidae) (e.g. Aragort et al. 2005, Davies et al. 2012, Magro et al. 2016). Few studies reported haemogregarines from marine teleost fishes from South Africa (Fantham 1930, Smit and Davies 1999, 2001, 2006, Davies and Smit 2001, Smit et al. 2003, Hayes et al. 2006, Ferreira et al. 2012). However, coccidian infections of chondrichthyans in South African waters have yet to be revealed.

\section{Myxozoans (Animalia, Cnidaria, Myxozoa)}

Myxozoans are multicellular parasites that have undergone a recent classification change from protists to the animal kingdom, where they are now accepted in the phylum Cnidaria (see Kent et al. 1994, Schlegel et al. 1996, Siddall et al. 1995, Okamura et al. 2015). Many myxozoans infect teleost fishes, but relatively few species are known from chondrichthyans. The primary site of infection is the lumen of the gall bladder (Love and Moser 1983, Cheung 1993). No species has thus far been recorded from chondrichthyans in South Africa.

Planarians (Animalia, Platyhelminthes, Rhabditophora, Tricladida)

Planarians are predominantly free-living flatworms. Only very few members adopted a parasitic mode of life. The tricladid species, Micropharynx parasitica Jägerskiöld, 1896 , is the only representative infecting chondrichthyans and has been reported from three species of skates (Rajidae) in the North Atlantic Ocean and the Barents Sea (Jägerskiöld 1896, Awerinzew 1925, Ball and Khan 1976). Although this tricladid has not been recorded from South Africa, its occurrence in these waters seems possible, due to the presence of one of its reported hosts. Raja clavata Linnaeus is a prominent and widely distributed species in the eastern Atlantic. It ranges from Iceland to South Africa and further into the western Indian Ocean to Madagascar (Froese and Pauly 2018). This species is only one of 26 reported species of rajids present in South African waters, 12 of which are endemic, and, to our knowledge, none of them has ever been examined for parasites.

Tapeworms (Lophotrochozoa, Platyhelminthes, Neodermata, Cestoda)

Cestodes or tapeworms are a large group of endoparasitic platyheminths, which successfully radiated in chondrichthyan hosts and now constitute by far the most diverse group of chondrichthyan parasites. The earliest record of a cestode infection comes from eggs found in a coprolite (fossil faeces) of an elasmobranch that dates back to the middle to late Permian Period, some 270 million years ago (Dentzien-Dias et al. 2013). A total of 19 cestode orders are currently recognised, 10 of which infect chondrichthyans, namely the Cathetocephalidea, Diphyllidea, Gyrocotylidea (only found in holocephalans), Lecanicephalidea, Litoboth- 
riidea, Onchoproteocephalidea II (sensu Caira et al. 2017), Phyllobothriidea, Rhinebothriidea, Tetraphyllidea relics (sensu Caira et al. 2017) and Trypanorhyncha (see Caira et al. 2017).

The diversity of cestodes infecting chondrichthyans is immense, with 203 known genera and 1,044 valid species (Caira et al. 2017). As such, cestodes are far more numerous than all other metazoan parasites infecting chondrichthyans. Within the Cestoda, trypanorhynchs comprise the largest group, with 81 genera and currently 315 recognised species (Beveridge et al. 2017). As mentioned earlier it is estimated that worldwide approximately 1,259 species of cestodes of elasmobranchs remain to be discovered (Caira et al. 2017). Holocephalans are on average less frequently parasitised. Randhawa and Poulin (2010) estimated an even higher species richness of cestodes infecting elasmobranchs. Assessing cestode records of 317 elasmobranch species, Randhawa and Poulin (2010) determined that roughly 3,600 have yet to be described.

Cestodes primarily infect the spiral intestine of their chondrichthyan definitive host. Caira and Healy (2004) stated that "it is very rare to encounter an elasmobranch in nature that does not host at least one species of cestode in its spiral intestine". On rare occasions, other parts of the chondrichthyan body are infected, such as the stomach and peritoneal cavity. Certain larval stages (mostly of the Trypanorhyncha) were also reported to infest the epidermis, gills, gall bladder, gonads, viscera and the peritoneal cavity. Although cestodes constitute the largest group of metazoan parasites of chondrichthyans, the known fauna from South Africa, at a first glance, seems rather depauperate.

At present, there are 23 species of seven orders recorded from South African waters, including 11 trypanorhynchs, six diphyllideans, two tetraphyllideans and one species of gyrocotylideans, onchoproteocephalideans, phyllobothriideans and rhinebothriideans, respectively (Linton 1924, Schramm 1989, 1991, Palm 1999, Rodriguez et al. 2011, Caira et al. 2013a, b, Abbott and Caira 2014, Bernot et al. 2015). The first cestode species of chondrichthyans from South Africa was recorded by Linton (1924) from the Cape Province (off Cape Town, Mossel Bay and Table Bay). Linton (1924) described two new species, Gyrocotyle plana Linton, 1924 (Gyrocotylidea) (now G. rugosa Diesing, 1850) and Echeneibothrium austrinum Linton, 1924 (Rhinebothriidea), and reported four additional species, namely Acanthobothrium paulum Linton, 1890 (Onchoproteocephalidea), Grillotia erinaceus (van Beneden, 1858), Hepatoxylon trichiuri (Holten, 1802) (both Trypanorhyncha) and Paraorygmatobothrium angustum (Linton, 1889) (Phyllobothriidea).

Since this first study, only very few scientists contributed to the knowledge of the South African cestode fauna of chondrichthyan hosts and findings from the 1980s until recently were opportunistic and not part of large-scale, systematic investigations. Overall, cestodes were recorded from 18 chondrichthyan host species of seven families, which is merely a fraction of the potential host spectrum of more than 200 chondrichthyan species present in South Africa (Ebert and van Hees 2015). Instead of having a de- pauperate fauna, it is probable that South Africa might yet reveal its potential of possessing a highly diverse cestode fauna likely to be even greater than the one of their chondrichthyan hosts.

\section{Monogeneans (Animalia, Platyhelminthes, Neodermata, Monogenea)}

Monogeneans belong to the flatworm phylum Platyhelminthes and represent a large group of highly host-specific parasites (Bychowsky 1957, Boeger and Kritsky 2001). They primarily attach to the gills and external surfaces of teleost fishes in marine and freshwater environments. Certain monogenean families (e.g. Acanthocotylidae, Amphibdellidae, Microbothriidae, Monocotylidae, Chimaericolidae and Hexabothriidae) or members thereof (e.g. Capsalidae, Dionchidae, Loimoidae, Udonellidae) parasitise chondrichthyans. The attachment sites on and within their chondrichthyan hosts are diverse and, apart from the gills and epidermis, they may infect the nasal fossae, urogenital system and the body cavity wall (Chisholm and Whittington 1998, Whittington et al. 2000).

In South Africa, research on marine monogeneans started with Manter (1955), who described two species from the Cape elephantfish, Callorhinchus capensis Duméril (Chimaeriformes: Callorhinchidae). At present, nine species of monogeneans belonging to three families have been recorded from eight species of chondrichthyans (Beverley-Burton et al. 1991, Bullard et al. 2004, Vaughan and Chisholm 2010a, b, 2011, Vaughan and Christison 2012, Poddubnaya et al. 2015, Vaughan et al. 2008). Given the high diversity of elasmobranchs and holocephalans in South African waters, it is expected that a large proportion of the monogenean diversity still remains to be discovered.

\section{Aspidogastreans (Animalia, Platyhelminthes,} Neodermata, Trematoda)

Aspidogastreans form a basal group of trematodes (flukes), sister to the Digenea (Rohde et al. 2001). Of the 61 aspidogastrean species known today, only 18 infect marine hosts (Alves et al. 2015), usually with a low intensity. Seven species were reported from chondrichthyans, namely Multicalyx cristata Faust et Tang, 1936, Multicalyx elegans (Olsson, 1869), Multicalyx sp., Rugogaster callorhinchi Amato et Pereira, 1995, Rugogaster hydrolagi Schell, 1973, Rugogaster sp. and Stichocotyle nephropis Cunningham, 1884 (see Alves et al. 2015). Of these, only a single species, M. cristata, was reported from South Africa from the gall bladder and spiral valve of Sphyrna lewini (Griffith et Smith) and the abdominal cavity of Carcharias taurus Rafinesque (Parukhin and Tkachuk 1980, Bray 1984).

\section{Digeneans (Animalia, Platyhelminthes, Neodermata,} Trematoda)

Digeneans are a speciose group of endoparasitic flatworms that are "primitively associated with teleosts" (Bray and Cribb 2003) and which greatly diversified amongst marine fishes. Infections of chondrichthyans, however, are considered a result of several host-switching events from 
teleosts over a long time period (Bray and Cribb 2003, Olson et al. 2003), while others account for accidental infections (see Caira et al. 2012). Overall, the diversity of digeneans in chondrichthyan hosts is rather limited and ranges between 50 and 60 species (Caira et al. 2012), which equals roughly $2.6 \%$ of the described digenean fauna (Caira et al. 2012). Among the numerous attachment sites, the preferred locations for digeneans are the body cavities (i.e. buccal, pericardial, and peritoneal cavity), the stomach, and, to a lesser extent, the heart and blood vessels (i.e. members of a single family), liver, oviducts, kidneys, rectum, cloaca and the spiral valve (Cribb et al. 2001, Caira et al. 2012).

Von Ofenheim (1900) was the first to report a species of digeneans from a chondrichthyan host from South Africa. The specimens were recovered from the body cavity of an unidentified cat shark species (Scyliorhinidae) collected in Cape Town. Von Ofenheim (1900) considered them conspecific with Probolitrema richiardii (López, 1888) (as Anaporrhutum ricchiardii), a species previously described from Squalus acanthias Linnaeus in the Mediterranean Sea. Soon after, Looss (1902) transferred the species into the newly erected genus Probolitrema Looss, 1902 and considered the specimens of von Ofenheim as a new species, Probolitrema capense Looss, 1902. The same species was later discovered by Gibson (1976) from a white skate, Rostroraja alba (Lacepède). However, Gibson (1976) synonymised nine species, including $P$. capense, with $P$. richiardii. This decision to synonymise $P$. capense with $P$. richiardii was later questioned by Yeld (2009), who found specimens allocated to ' $P$. capense' from the dark shyshark, Haploblepharus pictus (Müller et Henle) off Cape Town. Parukhin (1966) described a second species, Probolitrema callorhynchi Parukhin, 1966, from the Cape elephantfish, Callorhinchus capensis Duméril collected in the southern Atlantic Ocean. At present, knowledge on digeneans infecting chondrichthyans in South Africa is sparse and the two species currently known from the body cavities of a callorhinchid, scyliorhinid and rajid host might not represent the actual diversity of digeneans present in these waters.

Acanthocephalans (Animalia, Syndermata,

Acanthocephala)

Acanthocephalans or spiny-headed worms are prominent endoparasites of teleosts (Crompton and Nickol 1985). Adult acanthocephalans possess a spiny, eversible proboscis with which they attach to the intestinal and stomach walls of their definitive hosts. Chondrichthyans are rarely infected and are mostly considered to represent accidental hosts. At present, 18 species were reported from elasmobranchs. Four species were exclusively found in elasmobranchs (Golvan et al. 1964, Golvan 1969, Bilqees and Khan 2005, Weaver and Smales 2014), which might serve as paratenic or even suitable definitive hosts. Infections of holocephalans are unknown. At present, there have been no reports of acanthocephalans parasitising chondrichthyans in South Africa.

\section{Nematodes (Animalia, Ecdysozoa, Nematoda)}

Nematodes (roundworms) constitute a large phylum of free-living and parasitic organisms. Between 80 and 100 species of parasitic nematodes are known from chondrichthyan hosts (Benz and Bullard 2004, Caira and Healy 2004). Most species infecting chondrichthyans are endoparasites living in the spiral intestine and stomach, while others occur in the brain, heart, liver, spleen, kidneys, ovaries, uterus, musculature and the body cavity. Very few species were also reported from external body surfaces, such as the gills (Adamson et al. 1987, Cheung 1993, Moravec, 2001, Aragort et al. 2002), nasal fossae (Cheung 1993) and from tumors and skin lesions (Adamson et al. 1987, Chabaud 1960, MacCallum 1925, Moravec 2001). A single physalopterid nematode, Proleptus obtusus Dujardin, 1845, has been described from an unidentified species of Rhinobatos Linck from South Africa (Baylis 1933). Moravec et al. (2002) redescribed this species based on material collected from a second host, the puffadder shyshark, H. edwardsii collected off the De Hoop Nature Reserve (Cape Province). Nematodes have never been in the focus of marine parasitological research in South Africa. A single species infecting elasmobranchs known to date represents only a mere fraction of the diversity and, as a consequence, many more species await discovery.

\section{Hirudineans (Animalia, Annelida, Clitellata, Hirudinea)}

Hirudineans (leeches) of the family Piscicolidae are obligate ectoparasites feeding on the blood of fishes in marine and freshwater systems (Sawyer 1986). Marine hirudineans remain rarely studied in South Africa and the only reports are based on teleost and crustacean hosts (Moore 1958, Utevsky 2004, 2007). The Ph.D. thesis of Eleanor Yeld from the University in Cape Town mentions marine leeches from external surfaces of three species of scyliorhinid catsharks, H. pictus, H. edwardsii and Poroderma africanum (Gmelin) (Yeld, 2009). The piscicolid leeches were tentatively assigned to Stibarobdella macrothela (Schmarda). However, these results have not been formally published. Although piscicolid leeches are known parasites of chondrichthyans (Sawyer 1986), not a single species has been reported from South Africa.

Sea snails (Animalia, Mollusca, Gastropoda,

Caenogastropoda, Neogastropoda)

The first and so far only ectoparasitic gastropod, Cancellaria cooperi Gabb, 1865 (Neogastropoda: Cancellariidae), was reported from California (USA) by O'Sullivan et al. (1987). This gastropod species is highly specialised to feeding on the blood of the Pacific electric ray, Tetronarce californica (Ayres) (Torpediniformes: Torpedinidae), and potentially other bottom-dwelling species of rays (O'Sullivan et al. 1987). It is highly unlikely to find this geographically-restricted gastropod species infecting chondrichthyan hosts in South Africa. However, since only limited information on the parasite infections of chondrichthyans is known and previous studies from South Africa only focused on few chondrichthyan hosts and even fewer, selected parasite groups, such an infection might have been 
simply overlooked. Moreover, electric rays (Torpedinidae) have never been in the focus of any parasitological study in South Africa.

\section{Mites (Animalia, Arthropoda, Chelicerata, Arachnida,} Acari)

Benz and Bullard (2004) reported an unidentified species of acariform mite from the heart lumen of a nurse shark collected in Florida Bay in the north-western Atlantic Ocean. Although this has been the first report of acariform mites infecting chondrichthyans, several others have been reported from the swim-bladder, gills, pharynx, oesophagus and the stomach wall of teleosts (Bykhovskaya-Pavlovskaya et al. 1964, Hare and Burt 1975, Ching and Parker 1983, Fain and Belpaire 1985, Fain and Lambrechts 1985). Until now, parasitic infections with acariform mites have neither been reported from chondrichthyan hosts in waters off South Africa in particular, nor the entire southern hemisphere in general.

Ostracods (Animalia, Arthropoda, Crustacea, Ostracoda)

Ostracods (seed shrimps) are generally free-living organisms. Only very few species were reported to parasitise the gills and nasal cavities of elasmobranchs (Wilson 1913, Harding 1966, Williams and Bunkley-Williams 1996, Bennett et al. 1997). However, none has been reported from South Africa.

Isopods (Animalia, Arthropoda, Crustacea, Malacostraca, Peracarida, Isopoda)

Parasitic isopods almost exclusively occur on external surfaces of the chondrichthyan hosts (i.e. epidermis, nasal fossae, gills, buccal cavity, cloaca; see Brusca 1981, Heupel and Bennett 1999, Smit and Basson 2002, Bunkley-Williams and Williams 1998). Few species are considered as endoparasites, present in the heart (Bird 1981), stomach (van Beneden 1861, Meinert 1877, Hurley 1961) and uterus (Bird 1981, Caira and Healy 2004). The fauna of parasitic isopods of chondrichthyans known from South Africa to date includes only two species; the gnathiid, Gnathia pantherina Smit et Basson, 2002 (see Smit and Basson 2002, Smit and Davies 2004, Hayes et al. 2007), and the cirolanid, Natatolana hirtipes (Milne-Edwards, 1840) (Barnard 1936).

\section{Amphipods (Animalia, Arthropoda, Crustacea,}

Malacostraca, Peracarida, Amphipoda)

Amphipods are malacostracan crustaceans, which have a laterally compressed body lacking a carapace. Although mostly free-living, certain species are facultative ectoparasites on a wide array of hosts (Bousfield 1987). Parasitic amphipods infecting fishes may spend some parts of their lives free in the water column and attach temporarily to the body surfaces of fish hosts to feed on the skin tissue and food items or simply using fishes as a means of transport ('hitch-hikers' sensu Bousfield 1987).

Chondrichthyan hosts mostly include species of the deep-sea, e.g. lantern sharks (Etmopteridae) or dogfish sharks (Squalidae), or of colder climates, e.g. rajid skates in the northwestern Atlantic (Vader and Romppainen 1986). The western coastline of South Africa might represent a suitable environment for parasitic amphipods, given the presence of the cold and slow-flowing Benguela Current and the occurrence of a large assemblage of potential etmopterid, dalatiid and rajid host species. However, no records of parasitic amphipods infecting chondrichthyans in South Africa can be found in the literature.

\section{Branchiurans (Animalia, Arthropoda, Crustacea,}

Ichthyostraca, Branchiura)

Branchiurans (fish lice) of the genus Argulus Müller, 1785 are dominant ectoparasites of teleosts, but have also been reported from chondrichthyans (Wilson 1902, 1904, Cressey 1972, 1978, Ross 1999, Caira and Healy 2004). In South Africa, very few species of Argulus are known from marine or brackish water teleost hosts (Barnard 1955a, Avenant-Oldewage 1994, Avenant-Oldewage and Oldewage 1995, Van As et al. 1999, Van As and Van As 2001, Smit et al. 2005), while records of branchiuran infections on chondrichthyans are entirely absent.

\section{Barnacles (Animalia, Arthropoda, Crustacea, \\ Hexanauplia, Thecostraca, Cirripedia)}

Cirripeds, commonly known as barnacles, are a minor arthropod group of predominantly sessile, suspension-feeding crustaceans. Very few genera of cirripeds made the evolutionary transition to a parasitic mode of life (Newman et al. 1969). Of these, a single species infects vertebrate hosts. The pedunculate barnacle, Anelasma squalicola (Lovén, 1845), parasitises several species of deep-sea lantern sharks (Etmopteridae) of the genera Etmopterus and Centroscyllium (Darwin 1851, Hickling 1963, Leung 2014).

The peduncle of $A$. squalicola is thereby used as a feeding device to absorb nutrients from its squaloid hosts and as a solid anchorage (Ommundsen et al. 2016), deeply embedded into the tissue of the head, abdomen, claspers, dorsal, pectoral and pelvic fins (Kabata 1970, Long and Waggoner 1993, Yano and Musick 2000) and even the buccal cavity (Yano and Musick 2000). As it was shown for other parasitic cirripeds (Reinhard 1956, Hoggarth 1990), A. squalicola has negative impacts on the reproductive organs of its hosts, actively impeding the development of testes and ovaries (Hickling 1963). Although A. squalicola possesses a cosmopolitan distribution (Yano and Musick 2000), its presence in South Africa infecting etmopterid sharks has never been demonstrated.

\section{Copepods (Animalia, Arthropoda, Crustacea, \\ Hexanauplia, Copepoda)}

Copepods are the most diverse and by far the best studied group of parasites of chondrichthyans in South Africa. These ectoparasitic arthropods are mostly detected on external surfaces of their hosts, such as the epidermis, gills, branchial chambers, nasal fossae, spiracles, eyes, buccal cavity, cloaca and the acoustic-lateralis system. Rather unusual findings of parasitic copepods were reported from external surfaces of embryos in utero (Nagasawa et al. 1998) 
and the nasal capsules penetrating into the olfactory lobe of the brain (Diebakate et al. 1997). At present, 70 valid species from 11 families of parasitic copepods are known from chondrichthyans in South Africa. In addition, six species have only recently been considered nomina nuda, whereas another 16 could not be identified to species level. This multitude of known species infecting cartilaginous fishes makes South Africa one of the best studied countries for this line of parasite research in the world and new copepod species are described frequently.

\section{CHONDRICHTHYANS AS HOSTS OF PARASITES FROM SOUTH AFRICA}

In South Africa, only a mere fraction of the expected parasite diversity has been reported from chondrichthyan hosts and available chondrichthyan parasite records are based on information collected from 90 species, including 24 unidentified ones. Even if the unidentified species are considered as valid host records, less than $50 \%$ of the chondrichthyan species known from South Africa have been investigated for parasites. Among the best-studied host species are the great white shark, Carcharodon carcharias (Linnaeus), with a total of 30 records (13 species of copepods), followed by the bull shark, Carcharhinus leucas (Müller et Henle), with 25 records (10 species of copepods and four species of cestodes) and the dusky shark, Carcharhinus obscurus (Lesueur), with 23 records (13 species of copepods and one species of monogeneans and cestodes, respectively). Overall, carcharhiniform sharks make up 50\% of all host records. Among the Carcharhiniformes, the requiem sharks (Carcharhinidae) represent the best-studied host group with 125 records (i.e. 30\% of all host records). Mackerel sharks (Lamniformes) represent the second-most studied host group, with 83 host records and nine species observed.

Other chondrichthyan orders have been less frequently reported (i.e. Chimaeriformes, Hexanchiformes, Torpediformes, Pristiophoriformes, Orectolobiformes), with less than ten records for each host group, or relatively few members of species-rich orders were observed for parasites (i.e. Squaliformes, Rhinopristiformes, Rajiformes, Myliobatiformes). Species reports of the Echinorhiniformes, Squatiniformes and Heterodontiformes are currently absent. Information on parasite infections of chondrichthyans in South Africa seems to be limited to the most charismatic selachiid orders Carcharhiniformes and Lamniformes. Parasite infections of batoids, holocephalans and the remaining selachiid orders remain almost entirely unexplored. Caira and Healy (2004) estimated that globally hundreds of elasmobranchs remain to be examined for parasites. This is particularly true for the South African chondrichthyan fauna, where our knowledge of the parasite diversity is, at best, fragmentary. Our current knowledge of the parasite diversity and host records from South Africa is compiled and checklists of parasite-host and host-parasite records are provided below.

\section{PARASITE-HOST LIST}

The classification and nomenclature of parasites follows Ruggiero et al. (2015) and WoRMS Editorial Board (2018). The phyla of Protozoa and Chromista are followed by the sub- and infrakingdom (if available) in parentheses. In Animalia, each class is followed by the subphylum (if available) in parentheses. Orders of Arthropoda, Mollusca, Nematoda and Platyhelminthes are followed by the subclass and superorder (if available) in parentheses. Parasite and host species are listed alphabetically. Host classification follows Last et al. (2016a, b - Batomorphi) and Weigmann (2016 - Selachii and Holocephali). Nomenclature of chondrichthyan species follows Froese and Pauly (2018). Each host species is followed by the order and family, in parentheses, and the respective study, where hosts were listed.

\section{Kingdom Protozoa}

\section{Phylum: Euglenozoa (Eozoa: Euglenozoa)}

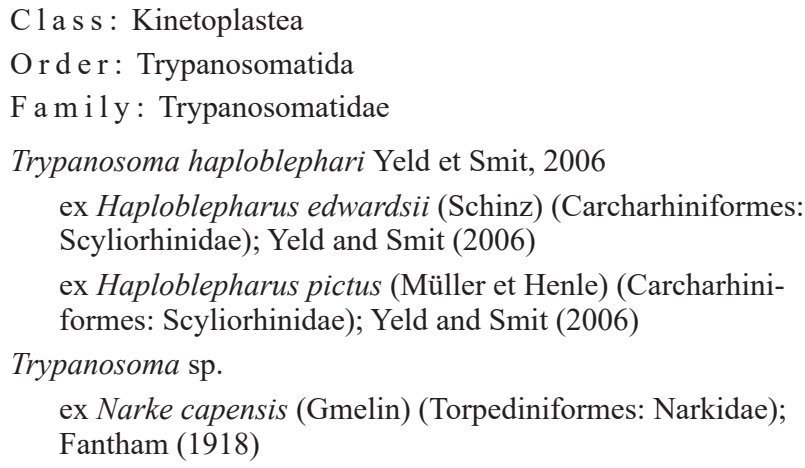

\section{Kingdom Chromista}

\section{Phylum: Ciliophora (Harosa: Aleolata)}

C1 as s: Oligohymenophorea

Orde r : Mobilida (Peritrichia)

F a mily: Trichodinidae

Trichodina rhinobatae Van As et Basson, 1996 ex Acroteriobatus annulatus (Müller et Henle) (Rhinopristiformes: Rhinobatidae); Van As and Basson (1996)

\section{Kingdom Animalia}

\section{Phylum: Platyhelminthes}

Clas s: Monogenea (Neodermata)

Order: Chimaericolidea (Polyopisthocotylea)

F a mi ly: Chimaericolidae

Callorhynchicola multitesticulatus Manter, 1955

ex Callorhinchus capensis Duméril (Chimaeriformes: Callorhinchidae); Manter (1955), Beverley-Burton et al. (1993)

C l as s: Monogenea (Neodermata)

Order: Diclybothriidea (Polyopisthocotylea)

F a mily: Hexabothriidae 
Branchotenthes robinoverstreeti Bullard et Dippenaar, 2003 ex Rhina ancylostoma Bloch et Schneider (Rhinopristiformes: Rhinidae); Bullard and Dippenaar (2003)

Callorhynchocotyle callorhynchi (Manter, 1955) ex Callorhinchus capensis Duméril (Chimaeriformes: Callorhinchidae); Manter (1955), Vaughan and Christison (2012), Poddubnaya et al. (2015)

Order: Monocotylidea (Monopisthocotylea)

F a mily: Monocotylidae

Dendromonocotyle citrosa Vaughan, Chisholm et Christison, 2008 ex Dasyatis chrysonota (Smith) (Myliobatiformes: Dasyatidae); Vaughan et al. (2008)

ex Maculabatis gerrardi (Gray) (Myliobatiformes: Dasyatidae); Vaughan et al. (2008) [in captivity]

Dendromonocotyle ukuthena Vaughan, Chisholm et Christison, 2008

ex Himantura cf. uarnak (Myliobatiformes: Dasyatidae); Vaughan et al. (2008) [in captivity] ex Maculabatis gerrardi (Gray) (Myliobatiformes: Dasyatidae); Vaughan et al. (2008) [in captivity]

Dermophthirius carcharhini MacCallum, 1926 ex Carcharhinus obscurus (Lesueur) (Carcharhiniformes: Carcharhinidae); Bullard et al. (2004)

Heterocotyle tokoloshei Vaughan et Chisholm, 2010 ex Bathytoshia brevicaudata (Hutton) (Myliobatiformes: Dasyatidae); Vaughan and Chisholm (2010a)

Neoheterocotyle robii Vaughan et Chisholm, 2010 ex Acroteriobatus annulatus (Müller et Henle) (Rhinopristiformes: Rhinobatida); Vaughan and Chisholm (2010b)

F a mily: Microbothriidae

Pseudoleptobothrium christisoni Vaughan et Chisholm, 2011 ex Acroteriobatus annulatus (Müller et Henle) (Rhinopristiformes: Rhinobatidae); Vaughan and Chisholm (2011)

Clas s: Trematoda (Neodermata)

Order: Aspidogastrida (Aspidogastrea)

Fa mily: Multicalycidae

Multicalyx cristata Faust et Tang, 1936

ex Carcharias taurus Rafinesque (Lamniformes: Odontaspinidae); Bray (1984)

ex Sphyrna lewini (Griffith et Smith) (Carcharhiniformes:

Sphyrnidae); Parukhin and Tkachuk (1980), Bray (1984)

Order: Plagiorchiida (Digenea)

Fa mily: Gorgoderidae

Probolitrema callorhynchi Parukhin, 1966 nomen nudum (Bray and Cribb, 2003)

ex Callorhinchus capensis Duméril (Chimaeriformes: Callorhinchidae); Parukhin $(1966,1968)$

Probolitrema richiardii (López, 1888)

ex Rostroraja alba (Lacepède) (Rajiformes: Rajidae); Gibson (1976)

ex Scyliorhinidae gen. sp. (Carcharhiniformes: Scyliorhinidae); von Ofenheim (1900)

Clas s : Cestoda (Neodermata)

Order: Gyrocotylidea (Cestodaria)

F a mily: Gyrocotylidae

Gyrocotyle rugosa Diesing, 1850 ex Callorhinchus callorynchus (Linnaeus) (Chimaeriformes: Callorhinchidae); Linton (1924)

Order: Diphyllidea (Eucestoda)

F a mily: Echinobothriidae

Andocadoncum meganae Abbott et Caira, 2014

ex Leucoraja wallacei (Hulley) (Rajiformes: Rajidae); Abbott and Caira (2014)

Echinobothrium dorothyae Caira, Pickering, Schulman et Hanessian, 2013

ex Raja straeleni Poll (Rajiformes: Rajidae); Caira et al. (2013a)

Echinobothrium dougbermani Caira, Pickering, Schulman et Hanessian, 2013

ex Rhinobatos annulatus Smith in Müller et Henle (Rhinopristiformes: Rhinobatidae); Caira et al. (2013a)

Echinobothrium joshuai Rodriguez, Pickering et Caira, 2011 ex Cruriraja hulleyi Aschliman, Ebert et Compagno (Rajiformes: Rajidae); Rodriguez et al. (2011)

Echinobothrium marquesi Abbott et Caira, 2014 ex Leucoraja wallacei (Hulley) (Rajiformes: Rajidae); Abbott and Caira (2014)

Echinobothrium yiae Caira, Rodriguez et Pickering, 2013 ex Raja miraletus Linnaeus (Rajiformes: Rajidae); Caira et al. (2013b)

Order: Onchoproteocephalidea (Eucestoda)

F a mily: Onchobothriidae

Acanthobothrium paulum Linton, 1890 ex Rajidae gen. sp. (Rajiformes: Rajidae); Linton (1924)

Orde r : Phyllobothriidea (Eucestoda)

F a mily: Phyllobothriidae

Paraorygmatobothrium angustum (Linton, 1889)

ex Carcharhinus melanopterus (Quoy et Gaimard) (Carcharhiniformes: Carcharhinidae); Linton (1924)

Order : Rhinebothriidea (Eucestoda)

F a mily: Echeneibothriidae

Echeneibothrium austrinum Linton, 1924

ex Rajidae gen. sp. (Rajiformes: Rajidae); Linton (1924)

Order: Tetraphyllidea (Eucestoda)

F a m i ly: Calliobothriidae

Calliobothrium euzeti Bernot, Caira et Pickering, 2015

ex Mustelus palumbes Smith (Carcharhiniformes: Triakidae); Bernot et al. (2015)

Symcallio peteri Bernot, Caira et Pickering, 2015 ex Mustelus palumbes Smith (Carcharhiniformes: Triakidae); Bernot et al. (2015)

Order: Trypanorhyncha (Eucestoda)

F a mily: Lacistorhynchidae

Grillotia erinaceus (van Beneden, 1858) ex Rajidae gen. sp. (Rajiformes: Rajidae); Linton (1924)

Pseudogrillotia perelica (Shuler, 1938) ex Carcharhinus leucas (Müller et Henle) (Carcharhiniformes: Carcharhinidae); Schramm (1991)

ex Carcharhinus plumbeus (Nardo) (Carcharhiniformes: Carcharhinidae); Schramm (1991) 
Family: Sphyriocephalidae

Hepatoxylon trichiuri (Holten, 1802)

ex Squalus acanthias Linnaeus (Squaliformes: Squalidae); Linton (1924)

F a m i ly: Tentaculariidae

Heteronybelinia estigmena (Dollfus, 1960)

ex Carcharhinus leucas (Müller et Henle) (Carcharhiniformes: Carcharhinidae); Palm (1999)

ex Carcharhinus limbatus (Müller et Henle) (Carcharhiniformes: Carcharhinidae); Palm (1999)

Heteronybelinia heteromorphi Palm, 1999 ex Sphyrna mokarran (Rüppell) (Carcharhiniformes: Sphyrnidae); Palm (1999)

Heteronybelinia robusta (Linton, 1890) ex Carcharhinus limbatus (Müller et Henle) (Carcharhiniformes: Carcharhinidae); Palm (1999)

Heteronybelinia yamagutii (Dollfus, 1960) ex Sphyrna lewini (Griffith et Smith) (Carcharhiniformes: Sphyrnidae); Palm (1999)

Nybelinia africana Dollfus, 1960

ex Carcharhinus leucas (Müller et Henle) (Carcharhiniformes: Carcharhinidae); Palm (1999)

ex Carcharhinus obscurus (Lesueur) (Carcharhiniformes: Carcharhinidae); Palm (1999)

ex Scylliogaleus queketti Boulenger (Carcharhiniformes: Triakidae); Palm (1999)

Nybelinia schmidti Palm, 1999

ex Prionace glauca (Linnaeus) (Carcharhiniformes: Carcharhinidae); Palm (1999)

Nybelinia scoliodoni (Vijayalakshmi, Vijayalakshmi et Gangdharam, 1996)

ex Carcharhinus limbatus (Müller et Henle) (Carcharhiniformes: Carcharhinidae); Palm (1999)

Fa mily: Otobothriidae

Poecilancistrium caryophyllum (Diesing, 1850)

ex Carcharhinus leucas (Müller et Henle) (Carcharhiniformes: Carcharhinidae); Schramm (1989)

\section{Phylum: Nematoda}

Clas s: Chromadorea

Order: Rhabditida (Chromadoria)

Fa mily: Physalopteridae

Proleptus obtusus Dujardin, 1845

ex Haploblepharus edwardsii (Schinz) (Carcharhiniformes: Scyliorhinidae); Moravec et al. (2002)

ex Rhinobatos sp. (Rhinopristiformes: Rhinobatidae); Baylis (1933)

\section{Phylum: Arthropoda}

C 1 a s s: Malacostraca (Crustacea)

Order: Isopoda (Eumalacostraca: Peracarida)

Family: Gnathiidae

Gnathia pantherina Smit et Basson, 2002

ex Acroteriobatus annulatus (Müller et Henle) (Rhinopristiformes: Rhinobatidae); Hayes et al. (2007)

ex Haploblepharus edwardsii (Schinz) (Carcharhiniformes:
Scyliorhinidae); Smit and Basson (2002), Smit and Davies (2004), Hayes et al. (2007)

ex Poroderma pantherium (Müller et Henle) (Carcharhiniformes: Scyliorhinidae); Smit and Basson (2002), Smit and Davies (2004)

ex Torpedo fuscomaculata Peters (Torpediniformes: Torpedinidae); Smit and Basson (2002), Smit and Davies (2004)

F a mily: Cirolanidae

Natatolana hirtipes (Milne-Edwards, 1840)

ex Carcharias sp. (Lamniformes: Odontaspididae); Barnard (1936)

C l a s s : Hexanauplia (Crustacea)

Order: Siphonostomatoida (Copepoda: Podoplea)

F a mi ly: Caligidae

Alebion carchariae Krøyer, 1863

ex Carcharhinus obscurus (Lesueur) (Carcharhiniformes:

Carcharhinidae); Kensley and Grindley (1973)

ex Carcharhinus sp. (Carcharhiniformes: Carcharhinidae); Barnard (1955a)

ex Carcharias taurus Rafinesque (Lamniformes: Odontaspididae); Oldewage and Smale (1993)

ex Carcharodon carcharias (Linnaeus) (Lamniformes: Lamnidae); Kensley and Grindley (1973)

ex Isurus oxyrinchus Rafinesque (Lamniformes: Lamnidae); Oldewage (1995)

ex Odontaspis sp. (Lamniformes: Odontaspididae); Kensley and Grindley (1973)

ex "shark"; Barnard (1955a), Kensley and Grindley (1973)

Alebion gracilis Wilson, 1905

ex Carcharhinus obscurus (Lesueur) (Carcharhiniformes:

Carcharhinidae); Cressey (1967b)

Alebion sp.

ex Carcharhinus obscurus (Lesueur) (Carcharhiniformes:

Carcharhinidae); Dippenaar (2009)

Caligus chrysophrysi Pillai, 1985

ex Mobula alfredi (Krefft) (Myliobatiformes: Mobulidae); Lebepe and Dippenaar (2013)

ex Mobula kuhlii (Müller et Henle) (Myliobatiformes: Mobulidae); Lebepe and Dippenaar (2013)

Caligus coryphaenae Steenstrup et Lütken, 1861

ex Carcharhinus leucas (Müller et Henle) (Carcharhiniformes: Carcharhinidae); Dippenaar and Jordaan (2007)

ex Carcharhinus obscurus (Lesueur) (Carcharhiniformes: Carcharhinidae); Dippenaar and Jordaan (2007)

ex Mobula kuhlii (Müller et Henle) (Myliobatiformes: Mobulidae); Dippenaar and Jordaan (2007)

ex Squalus acanthias Linnaeus (Squaliformes: Squalidae); Barnard (1955a)

ex "shark"; Barnard (1955b)

Euryphorus brachypterus (Gerstaecker, 1853)

ex "shark"; Oldewage and Avenant-Oldewage (1993)

Lepeophtheirus longispinosus Wilson, 1908

ex Carcharhinus leucas (Müller et Henle) (Carcharhiniformes: Carcharhinidae); Kensley and Grindley (1973), Dippenaar and Jordaan (2007)

ex Carcharhinus limbatus (Müller et Henle) (Carcharhiniformes: Carcharhinidae); Dippenaar and Jordaan (2007) ex Squalus megalops (Macleay) (Squaliformes: Squalidae); Oldewage (1992a), Oldewage and Avenant-Oldewage (1993) 
Lepeophtheirus natalensis Kensley et Grindley, 1973 ex Carcharhinus leucas (Müller et Henle) (Carcharhiniformes: Carcharhinidae); Kensley and Grindley (1973) Dippenaar and Jordaan (2007)

ex Carcharias taurus Rafinesque (Lamniformes: Odontaspididae); Olivier et al. (2000), Dippenaar and Jordaan (2007), Dippenaar (2009)

Lepeophtheirus sp.

ex Rhinobatos sp. (Rhinopristiformes: Rhinobatidae); Barnard (1955a)

Paralebion elongatus Wilson, 1911

ex Carcharhinus amboinensis (Müller et Henle) (Carcharhiniformes: Carcharhinidae); Dippenaar and Jordaan (2007) ex Carcharhinus leucas (Müller et Henle) (Carcharhiniformes: Carcharhinidae); Cressey (1967a, b), Dippenaar and Jordaan (2007), Dippenaar (2009),

ex Carcharhinus limbatus (Müller et Henle) (Carcharhiniformes: Carcharhinidae); Dippenaar and Jordaan (2007)

ex Carcharhinus obscurus (Lesueur) (Carcharhiniformes: Carcharhinidae); Dippenaar and Jordaan (2007)

Pupulina cliffi Dippenaar et Lebepe, 2013

ex Mobula eregoodootenkee (Bleeker) (Myliobatiformes: Mobulidae); Dippenaar and Lebepe (2013), Lebepe and Dippenaar (2013)

ex Mobula kuhlii (Müller et Henle) (Myliobatiformes: Mobulidae); Dippenaar and Lebepe (2013), Lebepe and Dippenaar (2013)

Pupulina merira Dippenaar et Lebepe, 2013 ex Mobula eregoodootenkee (Bleeker) (Myliobatiformes: Mobulidae); Dippenaar and Lebepe (2013), Lebepe and Dippenaar (2013)

ex Mobula kuhlii (Müller et Henle) (Myliobatiformes: Mobulidae); Dippenaar and Lebepe (2013), Lebepe and Dippenaar (2013)

F a mily: Dichelesthiidae

Anthosoma crassum (Abildgaard, 1794)

ex Carcharias taurus Rafinesque (Lamniformes: Odontaspididae); Dippenaar and Jordaan (2007)

ex Carcharias spp. (Lamniformes: Odontaspididae); Barnard (1955a)

ex Carcharodon carcharias (Linnaeus) (Lamniformes: Lamnidae); Dippenaar and Jordaan (2007), Kensley and Grindley (1973), Oldewage and Smale (1993)

ex Isurus oxyrinchus Rafinesque (Lamniformes: Lamnidae); Dippenaar and Jordaan (2007), Kensley and Grindley (1973), Oldewage and Smale (1993)

ex Isurus sp. (Lamniformes: Lamnidae); Cressey (1967b), Kensley and Grindley (1973)

ex Lamna nasus (Bonnaterre) (Lamniformes: Lamnidae); Barnard (1955a)

ex Mobula alfredi (Krefft) (Myliobatiformes: Mobulidae); Lebepe and Dippenaar (2013)

ex Mobula birostris (Walbaum) (Myliobatiformes: Mobulidae); Dippenaar and Jordaan (2007)

ex Odontaspis sp. (Lamniformes: Odontaspididae); Kensley and Grindley (1973)

ex Prionace glauca (Linnaeus) (Carcharhiniformes:

Carcharhinidae); Kensley and Grindley (1973)

F a mily: Eudactylinidae

Carnifossorius siamensis Deets et Ho, 1988

ex Rhina ancylostoma Bloch et Schneider (Rhinopristi- formes: Rhinidae); Dippenaar and Jordaan (2007)

Eudactylina acanthii Scott, 1901

ex Squalus megalops (Macleay) (Squaliformes: Squalidae); Dippenaar and Molele (2015)

Eudactylina aspera Heller, 1865

ex Carcharhinus limbatus (Müller et Henle) (Carcharhiniformes: Carcharhinidae); Dippenaar and Jordaan (2007)

ex Sphyrna lewini (Griffith et Smith) (Carcharhiniformes: Sphyrnidae); Dippenaar and Jordaan (2007)

Eudactylina diabolophila Deets, 1994 (nomen nudum) ex Mobula alfredi (Krefft) (Myliobatiformes: Mobulidae); Lebepe and Dippenaar (2013)

Eudactylina dollfusi Brian, 1924 ex Carcharhinus obscurus (Lesueur) (Carcharhiniformes: Carcharhinidae); Dippenaar and Jordaan (2007) ex Carcharhinus plumbeus (Nardo) (Carcharhiniformes: Carcharhinidae); Dippenaar and Jordaan (2007)

Eudactylina hornbosteli Deets, 1994 (nomen nudum) ex Aetobatus narinari (Euphrasen) (Myliobatiformes: Aetobatidae); Dippenaar and Jordaan (2007)

Eudactylina oliveri Laubier, 1968

ex Mobula kuhlii (Müller et Henle) (Myliobatiformes: Mobulidae); Dippenaar and Jordaan (2007), Lebepe and Dippenaar (2013)

ex Mobula eregoodootenkee (Bleeker) (Myliobatiformes: Mobulidae); Lebepe and Dippenaar (2013)

Eudactylina pollex Cressey, 1967 ex Sphyrna mokarran (Rüppell) (Carcharhiniformes: Sphyrnidae); Dippenaar and Jordaan (2007)

Eudactylina pusilla Cressey, 1967 ex Galeocerdo cuvier (Péron et Lesueur) (Carcharhiniformes: Carcharhinidae); Dippenaar (2009), Dippenaar and Jordaan (2007), Dippenaar et al. (2009)

Eudactylina vaquetillae Deets, 1994 (nomen nudum) ex Mobula kuhlii (Müller et Henle) (Myliobatiformes: Mobulidae); Lebepe and Dippenaar (2013)

Eudactylina sp.

ex Squalus cf. megalops (Squaliformes: Squalidae); Dikgale and Dippenaar (2010)

Eudactylinodes niger (Wilson, 1905) ex Carcharias taurus Rafinesque (Lamniformes: Odontaspididae); Dippenaar (2009), Dippenaar and Jordaan (2007)

Nemesis lamna Risso, 1826

ex Carcharodon carcharias (Linnaeus) (Lamniformes: Lamnidae); Cressey (1967b), Kensley and Grindley (1973), Dippenaar et al. (2008), Dippenaar (2009), Mangena et al. (2014)

ex Isurus oxyrinchus Rafinesque (Lamniformes: Lamnidae); Oldewage and Smale (1993), Dippenaar (2009), Mangena et al. (2014)

ex Isurus sp. (Lamniformes: Lamnidae); Cressey (1967b)

Nemesis robusta (van Beneden, 1851)

ex Alopias vulpinus (Bonnaterre) (Lamniformes: Alopiidae); Barnard (1948, 1955a), Kensley and Grindley (1973)

ex Prionace glauca (Linnaeus) (Carcharhiniformes:

Carcharhinidae); Kensley and Grindley (1973

Nemesis sp.

ex Squalus megalops (Macleay) (Squaliformes: Squalidae);

Dippenaar and Molele (2015)

Nemesis sp. 1 
ex Carcharhinus brevipinna (Müller et Henle) (Carcharhiniformes: Carcharhinidae); Mangena et al. (2014)

ex Sphyrna lewini (Griffith et Smith) (Carcharhiniformes: Sphyrnidae); Mangena et al. (2014)

Nemesis sp. 2

ex Carcharhinus brevipinna (Müller et Henle) (Carcharhiniformes: Carcharhinidae); Mangena et al. (2014)

Nemesis sp. 3

ex Alopias vulpinus (Bonnaterre) (Lamniformes: Alopiidae); Dippenaar (2009), Mangena et al. (2014)

ex Carcharhinus limbatus (Müller et Henle) (Carcharhiniformes: Carcharhinidae); Dippenaar (2009), Mangena et al. (2014)

ex Carcharhinus obscurus (Lesueur) (Carcharhiniformes: Carcharhinidae); Dippenaar (2009), Mangena et al. (2014) ex Carcharhinus sealei (Pietschmann) (Carcharhiniformes: Carcharhinidae); Dippenaar (2009)

ex Sphyrna lewini (Griffith et Smith) (Carcharhiniformes: Sphyrnidae); Mangena et al. (2014)

Nemesis sp. 4

ex Carcharhinus obscurus (Lesueur) (Carcharhiniformes: Carcharhinidae); Dippenaar (2009)

Nemesis sp. 5 ex Carcharhinus brevipinna (Müller et Henle) (Carcharhiniformes: Carcharhinidae); Dippenaar (2009)

Family: Kroyeriidae

Kroeyerina mobulae Deets, 1987 ex Mobula kuhlii (Müller et Henle) (Myliobatiformes: Mobulidae); Lebepe and Dippenaar (2013)

Kroeyerina scottorum Cressey, 1972

ex Sphyrna lewini (Griffith et Smith) (Carcharhiniformes: Sphyrnidae); Dippenaar and Jordaan (2007)

Kroyeria carchariaeglauci Hesse, 1878 ex Carcharhinus amboinensis (Müller et Henle) (Carcharhiniformes: Carcharhinidae); Mokumo and Dippenaar (2015)

ex Carcharhinus leucas (Müller et Henle) (Carcharhiniformes: Carcharhinidae); Dippenaar and Jordaan (2007), Mokumo and Dippenaar (2015)

ex Prionace glauca (Linnaeus) (Carcharhiniformes: Carcharhinidae); Kensley and Grindley (1973)

Kroyeria decepta Deets, 1994 (nomen nudum)

ex Carcharhinus obscurus (Lesueur) (Carcharhiniformes: Carcharhinidae); Dippenaar and Jordaan (2007), Dippenaar (2009), Mokumo and Dippenaar (2015)

Kroyeria deetsi Dippenaar, Benz et Olivier, 2000

ex Carcharhinus brevipinna (Müller et Henle) (Carcharhiniformes: Carcharhinidae); Dippenaar et al. (2000a), Mokumo and Dippenaar (2015)

Kroyeria dispar Wilson, 1935

ex Galeocerdo cuvier (Péron et Lesueur) (Carcharhiniformes: Carcharhinidae); Dippenaar (2009), Dippenaar et al. (2009), Mokumo and Dippenaar (2015)

Kroyeria gemursa Cressey, 1967

ex Sphyrna mokarran (Rüppell) (Carcharhiniformes: Sphyrnidae); Dippenaar and Jordaan (2007), Mokumo and Dippenaar (2015)

Kroyeria lineata van Beneden, 1853

ex Mustelus palumbes Smith (Carcharhiniformes: Triakidae); Mokumo and Dippenaar (2015)
Kroyeria longicauda Cressey, 1970

ex Carcharhinus limbatus (Müller et Henle) (Carcharhiniformes: Carcharhinidae); Dippenaar and Jordaan (2007), Dippenaar (2009), Mokumo and Dippenaar (2015)

Kroyeria papillipes Wilson, 1932

ex Galeocerdo cuvier (Péron et Lesueur) (Carcharhiniformes: Carcharhinidae); Dippenaar and Jordaan (2007), Dippenaar (2009), Dippenaar et al. (2009), Mokumo and Dippenaar (2015)

Kroyeria procerobscena Deets, 1994 (nomen nudum) ex Carcharhinus amboinensis (Müller et Henle) (Carcharhiniformes: Carcharhinidae); Dippenaar and Jordaan (2007), Mokumo and Dippenaar (2015)

ex Carcharhinus leucas (Müller et Henle) (Carcharhiniformes: Carcharhinidae); Dippenaar and Jordaan (2007), Mokumo and Dippenaar (2015)

Kroyeria rhophemophaga Deets, 1994 (nomen nudum) ex Galeorhinus galeus (Linnaeus) (Carcharhiniformes: Triakidae); Mokumo and Dippenaar (2015)

Kroyeria sphyrnae Rangnekar, 1957 ex Sphyrna lewini (Griffith et Smith) (Carcharhiniformes: Sphyrnidae); Dippenaar et al. (2001), Dippenaar (2009), Mokumo and Dippenaar (2015)

ex Sphyrna zygaena (Linnaeus) (Carcharhiniformes: Sphyrnidae); Dippenaar et al. (2001), Mokumo and Dippenaar (2015)

Kroyeria sp. ex Carcharhinus brevipinna (Müller et Henle) (Carcharhiniformes: Carcharhinidae); Dippenaar et al. (2000c)

F a mily: Lernaeopodidae

Charopinus dalmanni (Retzius, 1829)

ex Haploblepharus edwardsii (Schinz) (Carcharhiniformes: Scyliorhinidae); Oldewage (1992a), Oldewage and Avenant-Oldewage (1993)

ex Squalus acanthias Linnaeus (Squaliformes: Squalidae); Oldewage (1993a)

Charopinus dubius Scott, 1901

ex Raja sp. (Rajiformes: Rajidae); Kensley and Grindley (1973)

ex Rajella caudaspinosa (von Bonde et Swart) (Rajiformes: Rajidae); Kensley and Grindley (1973)

ex Rajella leoparda (von Bonde et Swart) (Rajiformes: Rajidae); Kensley and Grindley (1973)

ex "skate" (Rajiformes: Rajidae); Barnard (1955a)

Lernaeopoda galei Krøyer, 1837 ex Mustelus mustelus (Linnaeus) (Carcharhiniformes: Triakidae); Barnard (1955a), Kensley and Grindley (1973) ex Rhizoprionodon acutus (Rüppell) (Carcharhiniformes: Carcharhinidae); Dippenaar and Jordaan (2007)

Lernaeopoda sp. ex Squalus megalops (Macleay) (Squaliformes: Squalidae); Dippenaar and Molele (2015)

Neoalbionella etmopteri (Yamaguti, 1939) ex Etmopterus sp. (Squaliformes: Etmopteridae); Kensley and Grindley (1973)

Pseudocharopinus pteromylaei Raibaut et Essafi, 1979 ex Aetomylaeus bovinus (Geoffroy Saint-Hilaire) (Myliobatiformes: Myliobatidae); Dippenaar (2012)

Pseudocharopinus bicaudatus (Krøyer, 1837) ex Squalus megalops (Macleay) (Squaliformes: Squalidae); Dippenaar and Molele (2015) 
Schistobrachia jordaanae Dippenaar, Olivier et Benz, 2004 ex Gymnura natalensis (Gilchrist et Thompson) (Myliobatiformes: Gymnuridae); Dippenaar et al. (2004)

Schistobrachia kabata Dippenaar, 2016 ex Dipturus doutrei (Cadenat) (Rajiformes: Rajidae); Kensley and Grindley (1973)

ex Leucoraja wallacei (Hulley) (Rajiformes: Rajidae); Dippenaar (2016)

ex Raja straeleni Poll (Rajiformes: Rajidae); Dippenaar (2016)

ex Rostroraja alba (Lacepède) (Rajiformes: Rajidae); Dippenaar (2016)

ex "skate" (Rajiformes: Rajidae); Barnard (1955b)

Vanbenedenia hydrolagae Oldewage, 1993

ex Hydrolagus sp. (Chimaeriformes: Chimaeridae); Oldewage (1993b)

F a mily: Pandaridae

Achtheinus dentatus Wilson, 1911

ex Carcharhinus leucas (Müller et Henle) (Carcharhiniformes: Carcharhinidae); Cressey (1967a, b), Dippenaar and Jordaan (2007)

ex Carcharhinus limbatus (Müller et Henle) (Carcharhiniformes: Carcharhinidae); Dippenaar and Jordaan (2007)

ex Carcharhinus obscurus (Lesueur) (Carcharhiniformes: Carcharhinidae); Cressey (1967b), Dippenaar and Jordaan (2007), Dippenaar (2009)

ex Carcharhinus sealei (Pietschmann) (Carcharhiniformes: Carcharhinidae); Dippenaar and Jordaan (2007)

ex Carcharodon carcharias (Linnaeus) (Lamniformes: Lamnidae); Kensley and Grindley (1973)

ex Haploblepharus edwardsii (Schinz) (Carcharhiniformes: Scyliorhinidae); Kensley and Grindley (1973), Oldewage and Avenant-Oldewage (1993)

ex Mustelus canis (Mitchill) (Carcharhiniformes: Triakidae); Kensley and Grindley (1973)

ex Mustelus mosis Hemprich et Ehrenberg (Carcharhiniformes: Triakidae); Dippenaar and Jordaan (2007)

ex Mustelus sp. (Carcharhiniformes: Triakidae); Cressey (1967b), Kensley and Grindley (1973)

ex Mustelus spp. (Carcharhiniformes: Triakidae); Cressey (1967a)

ex Scoliodon sp. (Carcharhiniformes: Carcharhinidae); Kensley and Grindley (1973)

ex Sphyrna zygaena (Linnaeus) (Carcharhiniformes: Sphyrnidae); Kensley and Grindley (1973)

ex Squalus acanthias Linnaeus (Squaliformes: Squalidae); Kensley and Grindley (1973)

ex Squalus blainville (Risso) (Squaliformes: Squalidae); Kensley and Grindley (1973)

ex Squalus megalops (Macleay) (Squaliformes: Squalidae); Oldewage and Avenant-Oldewage (1993)

ex "shark"; Kensley and Grindley (1973)

Achtheinus oblongus Wilson, 1908

ex Carcharodon carcharias (Linnaeus) (Lamniformes: Lamnidae); Barnard (1955a), Oldewage and Smale (1993), Dippenaar and Jordaan (2007), Dippenaar (2009)

ex Haploblepharus edwardsii (Schinz) (Carcharhiniformes: Scyliorhinidae); Oldewage (1992a)

ex Hexanchus griseus (Bonnaterre) (Hexanchiformes: Hexanchidae); Oldewage and Smale (1993)

ex Mustelus mustelus (Linnaeus) (Carcharhiniformes:
Triakidae); Oldewage (1992a), Oldewage and Avenant-Oldewage (1993), Oldewage and Smale (1993)

ex Mustelus sp. (Carcharhiniformes: Triakidae); Barnard (1955a)

ex Pliotrema warreni Regan (Pristiophoriformes: Pristiophoridae); Wilson (1923), Kensley and Grindley (1973), Oldewage and Smale (1993)

ex Squalus acanthias Linnaeus (Squaliformes: Squalidae); Oldewage (1993a), Wilson (1923)

ex Squalus megalops (Macleay) (Squaliformes: Squalidae); Oldewage (1992a, 1993a), Oldewage and Smale (1993)

ex "dogfish"; Barnard (1955a)

ex Squalus cf. megalops (Squaliformes: Squalidae); Dikgale and Dippenaar (2010)

Achtheinus pinguis Wilson, 1912

ex Carcharhinus taurus Rafinesque (Lamniformes: Odontaspididae); Barnard (1955a), Dippenaar and Jordaan (2015)

ex Carcharodon carcharias (Linnaeus) (Lamniformes: Lamnidae); Dippenaar and Jordaan (2015)

ex Galeorhinus galeus (Linnaeus) (Carcharhiniformes: Triakidae); Dippenaar and Jordaan (2015)

ex Mustelus mustelus (Linnaeus) (Carcharhiniformes: Triakidae); Oldewage (1992b)

ex Rhizoprionodon acutus (Rüppell) (Carcharhiniformes: Carcharhinidae); Barnard (1955a)

ex Pliotrema warreni Regan (Pristiophoriformes: Pristiophoridae); Barnard (1955a)

ex Scyliorhinus sp. (Carcharhiniformes: Scyliorhinidae); Barnard (1955a)

ex Squalus acanthias Linnaeus (Squaliformes: Squalidae); Barnard (1955a)

ex Squalus megalops (Macleay) (Squaliformes: Squalidae); Oldewage (1992b), Dippenaar and Molele (2015)

ex Squalus cf. megalops (Squaliformes: Squalidae); Dippenaar and Jordaan (2015)

ex "shark"; Barnard (1955a)

Dinemoura latifolia (Steenstrup et Lütken, 1861)

ex Isurus oxyrinchus Rafinesque (Lamniformes: Lamnidae); Oldewage and Smale (1993)

ex Prionace glauca (Linnaeus) (Carcharhiniformes:

Carcharhinidae); Cressey (1967b), Kensley and Grindley (1973), Oldewage (1992c)

ex Prionace sp. (Carcharhiniformes: Carcharhinidae); Kensley and Grindley (1973)

Echthrogaleus coleoptratus (Guérin-Méneville, 1837)

ex Carcharodon carcharias (Linnaeus) (Lamniformes: Lamnidae); Oldewage and Smale (1993)

ex Prionace glauca (Linnaeus) (Carcharhiniformes: Carcharhinidae); Barnard (1955a), Kensley and Grindley (1973)

Echthrogaleus denticulatus Smith, 1873

ex Isurus oxyrinchus Rafinesque (Lamniformes: Lamnidae); Oldewage and Smale (1993)

Echthrogaleus torpedinis Wilson, 1907

ex Tetronarce nobiliana (Bonaparte) (Torpediniformes: Torpedinidae); Kensley and Grindley (1973)

ex Torpedo sp. (Torpediniformes: Torpedinidae); Kensley and Grindley (1973)

Entepherus laminipes Bere, 1936

ex Mobula alfredi (Krefft) (Myliobatiformes: Mobulidae); Lebepe and Dippenaar (2013) 
ex Mobula birostris (Walbaum) (Myliobatiformes: Mobulidae); Dippenaar and Jordaan (2007)

ex Mobula kuhlii (Müller et Henle) (Myliobatiformes: Mobulidae); Lebepe and Dippenaar (2013)

Nesippus crypturus Heller, 1868

ex Carcharinus brevipinna (Müller et Henle) (Carcharhiniformes: Carcharhinidae); Dippenaar and Jordaan (2012) ex Carcharinus leucas (Müller et Henle) (Carcharhiniformes: Carcharhinidae); Dippenaar and Jordaan (2012) ex Carcharinus limbatus (Müller et Henle) (Carcharhiniformes: Carcharhinidae); Dippenaar and Jordaan (2012) ex Carcharodon carcharias (Linnaeus) (Lamniformes: Lamnidae); Dippenaar and Jordaan (2012)

ex Galeocerdo cuvier (Péron et Lesueur) (Carcharhiniformes: Carcharhinidae); Dippenaar and Jordaan (2012) ex Sphyrna mokarran (Rüppell) (Carcharhiniformes: Sphyrnidae); Dippenaar (2009), Dippenaar and Jordaan (2012)

ex Sphyrna zygaena (Linnaeus) (Carcharhiniformes: Sphyrnidae); Dippenaar and Jordaan (2012)

Nesippus nana Cressey, 1970 ex Carcharinus plumbeus (Nardo) (Carcharhiniformes: Carcharhinidae); Dippenaar and Jordaan (2012)

Nesippus orientalis Heller, 1868

ex Alopias vulpinus (Bonnaterre) (Lamniformes: Alopiidae); Dippenaar and Jordaan $(2006,2012)$

ex Carcharhinus brachyurus (Günther) (Carcharhiniformes: Carcharhinidae); Dippenaar et al. (2010)

ex Carcharhinus brevipinna (Müller et Henle) (Carcharhiniformes: Carcharhinidae); Dippenaar and Jordaan (2006) ex Carcharhinus leucas (Müller et Henle) (Carcharhiniformes: Carcharhinidae); Dippenaar and Jordaan (2006), Dippenaar et al. (2010)

ex Carcharhinus limbatus (Müller et Henle) (Carcharhiniformes: Carcharhinidae); Dippenaar and Jordaan (2006), Dippenaar et al. (2010)

ex Carcharias taurus Rafinesque (Lamniformes: Odontaspididae); Dippenaar and Jordaan (2006), Dippenaar (2009),

Dippenaar et al. (2010)

ex Carcharodon carcharias (Linnaeus) (Lamniformes: Lamnidae); Barnard (1955a), Cressey (1967b), Kensley and Grindley (1973), Dippenaar and Jordaan (2006, 2012), Dippenaar (2009), Dippenaar et al. (2010)

ex Isurus oxyrinchus Rafinesque (Lamniformes: Lamnidae); Dippenaar (2009), Dippenaar and Jordaan (2006), Dippenaar et al. (2010)

ex Mustelus mustelus (Linnaeus) (Carcharhiniformes:

Triakidae); Dippenaar and Jordaan (2012)

ex Sphyrna lewini (Griffith et Smith) (Carcharhiniformes:

Sphyrnidae); Dippenaar and Jordaan (2006), Dippenaar et al. (2010)

ex Sphyrna mokarran (Rüppell) (Carcharhiniformes:

Sphyrnidae); Dippenaar and Jordaan $(2006,2012)$, Dippenaar et al. (2010)

ex Sphyrna zygaena (Linnaeus) (Carcharhiniformes: Sphyrnidae); Cressey (1967a, b), Kensley and Grindley (1973), Dippenaar and Jordaan (2006, 2012), Dippenaar (2009)

Nesippus tigris Cressey, 1967

ex Galeocerdo cuvier (Péron et Lesueur) (Carcharhiniformes: Carcharhinidae); Dippenaar and Jordaan $(2007,2012)$

ex Carcharodon carcharias (Linnaeus) (Lamniformes: Lamnidae); Dippenaar and Jordaan (2012)
Nesippus vespa Kirtesinghe, 1964

ex Rhina ancylostoma Bloch et Schneider (Rhinopristiformes: Rhinidae); Dippenaar and Jordaan (2007, 2012), Dippenaar (2009)

ex Rhynchobatus djiddensis (Forsskål) (Rhinopristiformes: Rhinidae); Dippenaar and Jordaan $(2007,2012)$

Pandarus bicolor Leach, 1816

ex Carcharhinus sp. (Carcharhiniformes: Carcharhinidae); Kensley and Grindley (1973)

ex Carcharias sp. (Lamniformes: Odontaspididae); Barnard (1948, 1955a)

ex Galeorhinus galeus (Linnaeus) (Carcharhiniformes: Triakidae); Barnard (1948, 1955a), Kensley and Grindley (1973), Oldewage and Smale (1993)

ex Odontaspis sp. (Lamniformes: Odontaspididae); Kensley and Grindley (1973)

ex Squalus acanthias Linnaeus (Squaliformes: Squalidae); Oldewage and Smale (1993)

ex "dogfish"; Kensley and Grindley (1973)

ex "grey shark"; Barnard (1955a)

Pandarus carcharini Ho, 1963

ex Carcharhinus leucas (Müller et Henle) (Carcharhiniformes: Carcharhinidae); Cressey (1967a, b)

ex "hammerhead shark" (Carcharhiniformes: Sphyrnidae); Barnard (1955a)

Pandarus cranchi Leach, 1819

ex Carcharhinus longimanus (Poey) (Carcharhiniformes: Carcharhinidae); Cressey (1967a, b)

ex Carcharodon carcharias (Linnaeus) (Lamniformes: Lamnidae); Cressey (1967b)

ex Poroderma africanum (Gmelin) (Carcharhiniformes: Scyliorhinidae); Barnard (1955a)

ex Sphyrna zygaena (Linnaeus) (Carcharhiniformes: Sphyrnidae); Kensley and Grindley (1973)

ex Sphyrna sp. (Carcharhiniformes: Sphyrnidae); Barnard (1948)

ex Stegostoma fasciatum (Hermann) (Orectolobiformes:

Stegostomatidae); Barnard (1948, 1955a)

ex Stegostoma sp. (Orectolobiformes: Stegostomatidae);

Kensley and Grindley (1973)

Pandarus floridanus Cressey, 1967

ex Carcharias taurus Rafinesque (Lamniformes: Odontaspididae); Oldewage and Smale (1993)

Pandarus smithii Rathbun, 1886

ex Carcharhinus obscurus (Lesueur) (Carcharhiniformes: Carcharhinidae); Kensley and Grindley (1973)

ex Carcharhinus sp. (Carcharhiniformes: Carcharhinidae); Barnard (1955a)

ex Carcharias taurus Rafinesque (Lamniformes: Odontaspididae); Oldewage and Smale (1993)

ex Carcharias sp. (Lamniformes: Odontaspididae); Barnard (1955a)

ex Carcharias spp. (Lamniformes: Odontaspididae); Barnard (1948)

ex Carcharodon carcharias (Linnaeus) (Lamniformes: Lamnidae); Kensley and Grindley (1973), Oldewage and Smale (1993)

ex Isurus oxyrinchus Rafinesque (Lamniformes: Lamnidae); Kensley and Grindley (1973), Oldewage and Smale (1993) ex Isurus sp. (Lamniformes: Lamnidae); Kensley and Grindley (1973) 
ex Odontaspis sp. (Lamniformes: Odontaspididae); Kensley and Grindley (1973)

ex Prionace glauca (Linnaeus) (Carcharhiniformes: Carcharhinidae); Kensley and Grindley (1973)

ex Rhincodon typus Smith (Orectolobiformes: Rhincodontidae); Kensley and Grindley (1973)

ex Scoliodon laticaudus Müller et Henle (Carcharhiniformes: Carcharhinidae); Kensley and Grindley (1973)

Pandarus sp. 1

ex Carcharias taurus Rafinesque (Lamniformes: Odontaspididae); Dippenaar (2009)

Pandarus sp. 2 ex Sphyrna lewini (Griffith et Smith) (Carcharhiniformes: Sphyrnidae); Dippenaar (2009)

Pandarus sp. 3 ex Carcharodon carcharias (Linnaeus) (Lamniformes: Lamnidae); Dippenaar (2009)

Pannosus japonicus (Shiino, 1960)

ex Sphyrna lewini (Griffith et Smith) (Carcharhiniformes: Sphyrnidae); Dippenaar and Jordaan (2007), Dippenaar (2009)

Phyllothyreus cornutus (Milne-Edwards, 1840)

ex Galeocerdo cuvier (Péron et Lesueur) (Carcharhiniformes: Carcharhinidae); Dippenaar and Jordaan (2007) ex Isurus oxyrinchus Rafinesque (Lamniformes: Lamnidae); Dippenaar and Jordaan (2007), Dippenaar (2009)

Pseudopandarus gracilis Kirtisinghe, 1950 ex Mustelus mosis Hemprich et Ehrenberg (Carcharhiniformes: Triakidae); Dippenaar and Jordaan (2007)

Pseudopandarus longus (Gnanamuthu, 1951)

ex Carcharhinus obscurus (Lesueur) (Carcharhiniformes: Carcharhinidae); Dippenaar and Jordaan (2007), Dippenaar (2009)

ex Carcharhinus sealei (Pietschmann) (Carcharhiniformes: Carcharhinidae); Dippenaar and Jordaan (2007)

ex Mustelus mosis Hemprich et Ehrenberg (Carcharhiniformes: Triakidae); Dippenaar and Jordaan (2007)

ex Rhizoprionodon acutus (Rüppell) (Carcharhiniformes: Carcharhinidae); Cressey (1967a, b), Dippenaar and Jordaan (2007)

ex Triaenodon obesus (Rüppell) (Carcharhiniformes: Carcharhinidae); Cressey (1967a, b)

F a mily: Sphyriidae

Tripaphylus beatricae Dippenaar, 2018

ex Mustelus mustelus (Linnaeus) (Carcharhiniformes:

Triakidae); Dippenaar (2018)

Tripaphylus benzi Dippenaar, 2018

ex Mustelus palumbes Smith (Carcharhiniformes: Triakidae); Dippenaar (2018)

Tripaphylus elongatus (Wilson, 1932)

ex Carcharhinus obscurus (Lesueur) (Carcharhiniformes: Carcharhinidae); Dippenaar and Jordaan (2007), Dippenaar (2009, 2018)

Tripaphylus hoi Dippenaar, 2018 ex Mustelus palumbes Smith (Carcharhiniformes: Triakidae); Dippenaar (2018)

Tripaphylus lewisi Dippenaar, 2018

ex Hemipristis elongata (Klunzinger) (Carcharhiniformes: Hemigaleidae); Dippenaar (2018)
Tripaphylus vaissierei (Delamare Deboutteville et Nuñes-Ruivo, 1954)

ex Sphyrna lewini (Griffith et Smith) (Carcharhiniformes: Sphyrnidae); Dippenaar and Jordaan (2007), Dippenaar (2018)

F a mily: Trebiidae

Trebius benzi Dippenaar, 2017

ex Squalus megalops (Macleay) (Squaliformes: Squalidae); Dippenaar (2017)

Trebius caudatus Krøyer, 1838 ex Rostroraja alba (Lacepède) (Rajiformes: Rajidae); Barnard $(1948,1955 a)$

ex "skate" (Rajiformes: Rajidae); Kensley and Grindley (1973)

Trebius sp.

ex Squalus megalops (Macleay) (Squaliformes: Squalidae); Dippenaar and Molele (2015)

\section{HOST-PARASITE LIST}

Higher level classification of the class Chondrichthyes follows Nelson et al. (2016). Ordinal and family level classification within the subclasses Euselachii and Holocephali follows Last et al. (2016a, b) (i.e. Batomorphi) and Weigmann (2016) (i.e. Selachii and Holocephali). Nomenclature of chondrichthyan species follows Froese and Pauly (2018). Parasite species in respective groups are listed alphabetically. Parasite groups are indicated by the following abbreviations: Cestoda $-\mathrm{Ce}$, Ciliophora $-\mathrm{Ci}$, Copepoda - Co, Isopoda - Is, Kinetoplastida - Ki, Monogenea - Mo, Nematoda - Ne, Trematoda - Tr.

\section{Class Chondrichthyes}

\section{Subclass: Holocephali}

Order: Chimaeriformes

F a mily: Callorhinchidae

Callorhinchus callorynchus (Linnaeus): $\mathrm{Ce}$ - Gyrocotyle rugosa Diesing, 1850

Callorhinchus capensis Duméril: Mo - Callorhynchocotyle callorhynchi (Manter, 1955); Callorhynchicola multitesticulatus Manter, 1955; Tr - Probolitrema callorhynchi Parukhin, 1966 (nomen nudum)

F a mily: Chimaeridae

Hydrolagus sp.: Co - Vanbenedenia hydrolagae Oldewage, 1993

\section{Subclass: Euselachii}

\section{Infraclass: Elasmobranchii}

\section{Division: Batomorphi}

Order: Rajiformes

F a mily: Rajidae

Cruriraja hulleyi Aschliman, Ebert et Compagno: $\mathrm{Ce}-$ Echinobothrium joshuai Rodriguez, Pickering et Caira, 2011

Dipturus doutrei (Cadenat): Co - Schistobrachia kabata Dippenaar, 2016 
Leucoraja wallacei (Hulley): Ce-Andocadoncum meganae Abbott et Caira, 2014; Echinobothrium marquesi Abbott et Caira, 2014; Co - Schistobrachia kabata Dippenaar, 2016

Raja miraletus Linnaeus: Ce - Echinobothrium yiae Caira, Rodriguez et Pickering, 2013

Raja straeleni Poll: Ce - Echinobothrium dorothyae Caira, Pickering, Schulman et Hanessian, 2013; Co - Schistobrachia kabata Dippenaar, 2016

Raja sp.: Co-Charopinus dubius Scott, 1901

Rajella caudaspinosa (von Bonde et Swart): Co - Charopinus dubius Scott, 1901

Rajella leoparda (von Bonde et Swart): Co - Charopinus dubius Scott, 1901

Rostroraja alba (Lacepède): Co - Schistobrachia kabata Dippenaar, 2016; Trebius caudatus Krøyer, 1838; Tr - Probolitrema richiardii (López, 1888)

Rajidae gen. sp.: Ce - Acanthobothrium paulum Linton, 1890; Echeneibothrium austrinum Linton, 1924; Grillotia erinaceus (van Beneden, 1858)

"skate": Co - Charopinus dubius Scott, 1901; Schistobrachia kabata Dippenaar, 2016; Trebius caudatus Krøyer, 1838

Order: Torpediniformes

F a mily: Narkidae

Narke capensis (Gmelin): Ki - Trypanosoma sp.

Family: Torpedinidae

Tetronarce nobiliana (Bonaparte): Co - Echthrogaleus torpedinis Wilson, 1907

Torpedo fuscomaculata Peters: Is - Gnathia pantherina Smit et Basson, 2002

Torpedo sp.: Co - Echthrogaleus torpedinis Wilson, 1907

Order: Rhinopristiformes

Fa mily: Rhinidae

Rhina ancylostoma Bloch et Schneider: Co - Carnifossorius siamensis Deets et Ho, 1988; Nesippus vespa Cressey, 1964; Mo - Branchotenthes robinoverstreeti Bullard et Dippenaar, 2003

Rhynchobatus djiddensis (Forsskål): Co - Nesippus vespa Cressey, 1964

Family: Rhinobatidae

Acroteriobatus annulatus (Müller et Henle): Ce - Echinobothrium dougbermani Caira, Pickering, Schulman et Hanessian, 2013; Ci - Trichodina rhinobatae Van As et Basson, 1996; Is - Gnathia pantherina Smit et Basson, 2002; Mo - Neoheterocotyle robii Vaughan et Chisholm, 2010; Pseudoleptobothrium christisoni Vaughan et Chisholm, 2011

Rhinobatos sp.: $\mathrm{Co}$ - Lepeophtheirus sp.; $\mathrm{Ne}$ - Proleptus obtusus Dujardin, 1845

Order: Myliobatiformes

Family: Aetobatidae

Aetobatis narinari (Euphrasen): Co - Eudactylina hornbosteli Deets, 1994 (nomen nudum)

Family: Dasyatidae

Bathytoshia brevicaudata (Hutton): Mo - Heterocotyle tokoloshei Vaughan et Chisholm, 2010

Dasyatis chrysonota (Smith): Mo - Dendromonocotyle citrosa Vaughan, Chisholm et Christison, 2008

Himantura cf. uarnak: Mo - Dendromonocotyle ukuthena Vaughan, Chisholm et Christison, 2008
Maculabatis gerrardi (Gray): Mo - Dendromonocotyle citrosa Vaughan, Chisholm et Christison, 2008; D. ukuthena Vaughan, Chisholm et Christison, 2008

F a mily: Gymnuridae

Gymnura natalensis (Gilchrist et Thompson): Co - Schistobrachia jordaanae Dippenaar, Olivier et Benz, 2004

Family: Mobulidae

Mobula alfredi (Krefft): Co - Anthosoma crassum (Abildgaard, 1794); Caligus chrysophrysi Pillai, 1985; Entepherus laminipes Bere, 1936; Eudactylina diabolophila Deets, 1994 (nomen nudum)

Mobula birostris (Walbaum): Co - Anthosoma crassum (Abildgaard, 1794); Entepherus laminipes Bere, 1936

Mobula eregoodootenkee (Bleeker): Co - Eudactylina oliveri Laubier, 1968; Pupulina cliffi Dippenaar et Lebepe, 2013; Pupulina merira Dippenaar et Lebepe, 2013

Mobula kuhlii (Müller et Henle): Co - Caligus chrysophrysi Pillai, 1985; Caligus coryphaenae Steenstrup et Lütken, 1861; Entepherus laminipes Bere, 1936; Eudactylina oliveri Laubier, 1968; E. vaquetillae Deets, 1994 (nomen nudum); Kroeyerina mobulae Deets, 1987; Pupulina cliffi Dippenaar et Lebepe, 2013; P. merira Dippenaar et Lebepe, 2013

Family: Myliobatidae

Aetomylaeus bovinus (Geoffroy Saint-Hilaire): Co - Pseudocharopinus pteromylaei Raibaut et Essafi, 1979

\section{Division: Selachii}

Order: Hexanchiformes

Fa mily: Hexanchidae

Hexanchus griseus (Bonnaterre): Co - Achtheinus oblongus Wilson, 1908

Order: Pristiophoriformes

Family: Pristiophoridae

Pliotrema warreni Regan: Co - Achtheinus oblongus Wilson, 1908; A. pinguis Wilson, 1912

Order: Squaliformes

Fa mily: Squalidae

Squalus acanthias Linnaeus: Ce - Hepatoxylon trichiuri (Holten, 1802); Co - Achtheinus dentatus Wilson, 1911; A. oblongus Wilson, 1908; A. pinguis Wilson, 1912; Caligus coryphaenae Steenstrup et Lütken, 1861; Charopinus dalmanni (Retzius, 1829); Pandarus bicolor Leach, 1816

Squalus blainville (Risso): Co - Achtheinus dentatus Wilson, 1911

Squalus megalops (Macleay): Co - Achtheinus dentatus Wilson, 1911; A. oblongus Wilson, 1908; A. pinguis Wilson, 1912; Eudactylina acanthi Scott, 1901; Lepeophtheirus longispinosus Wilson, 1908; Lernaeopoda sp.; Nemesis sp.; Pseudocharopinus bicaudatus (Krøyer, 1837); Trebius benzi Dippenaar, 2017; Trebius sp.

Squalus cf. megalops: Co - Achtheinus oblongus Wilson, 1908; A. pinguis Wilson, 1912; Eudactylina sp.

“dogfish": Co - Achtheinus oblongus Wilson, 1908; Pandarus bicolor Leach, 1816

F a mily: Etmopteridae

Etmopterus sp.: Co - Neoalbionella etmopteri (Yamaguti, 1939)

Order: Orectolobiformes 
Fa mily: Rhincodontidae

Rhincodon typus Smith: Co - Pandarus smithii Rathbun, 1886

Family: Stegostomatidae

Stegostoma fasciatum (Hermann): Co - Pandarus cranchi Leach, 1819

Stegostoma sp.: Co - Pandarus cranchi Leach, 1819

Order: Lamniformes

Family: Alopiidae

Alopias vulpinus (Bonnaterre): Co - Nemesis robusta (van Beneden, 1851); Nemesis sp. 3; Nesippus orientalis Heller, 1865

F a mily: Odontaspididae

Carcharias taurus Rafinesque: Co - Achtheinus pinguis Wilson, 1912; Alebion carchariae Krøyer, 1863; Anthosoma crassum (Abildgaard, 1794); Eudactylinodes niger (Wilson, 1905); Lepeophtheirus natalensis Kensley et Grindley, 1973; Nesippus orientalis Heller, 1865; Pandarus floridanus Cressey, 1967; P. smithii Rathbun, 1886; Pandarus sp. 1; Tr - Multicalyx cristata Faust et Tang, 1936

Carcharias sp.: Co - Anthosoma crassum (Abildgaard, 1794); Pandarus bicolor Leach, 1816; P. smithii Rathbun, 1886; Is - Natatolana hirtipes (H. Milne-Edwards, 1840)

Odontaspis sp.: Co - Alebion carchariae Krøyer, 1863; Anthosoma crassum (Abildgaard, 1794); Pandarus bicolor Leach, 1816; P. smithii Rathbun, 1886

Fa mily: Lamnidae

Carcharodon carcharias (Linnaeus): $\mathrm{Co}-$ Achtheinus dentatus Wilson, 1911; A. oblongus Wilson, 1908; A. pinguis Wilson, 1912; Alebion carchariae Krøyer, 1863; Anthosoma crassum (Abildgaard, 1794); Echthrogaleus coleoptratus (GuérinMéneville, 1837); Nemesis lamna Risso, 1826; Nesippus crypturus Heller, 1868; $N$. orientalis Heller, 1868; N. tigris Cressey, 1967; Pandarus cranchi Leach, 1819; P. smithii Rathbun, 1886; Pandarus sp. 3

Isurus oxyrinchus Rafinesque: Co - Alebion carchariae Krøyer, 1863; Anthosoma crassum (Abildgaard, 1794); Dinemoura latifolia (Steenstrup et Lütken, 1861); Echthrogaleus denticulatus Smith, 1873; Nemesis lamna Risso, 1826; Nesippus orientalis Heller, 1865; Pandarus smithii Rathbun, 1886; Phyllothyreus cornutus (Milne-Edwards, 1840)

Isurus sp.: Co - Anthosoma crassum (Abildgaard); Nemesis lamna Risso, 1826; Pandarus smithii Rathbun, 1886

Lamna nasus (Bonnaterre): Co - Anthosoma crassum (Abildgaard, 1794)

Order: Carcharhiniformes

F a mily: Scyliorhinidae

Haploblepharus edwardsii (Schinz): Co - Achtheinus dentatus Wilson, 1911; A. oblongus Wilson, 1908; Charopinus dalmanni (Retzius, 1829); Ne - Proleptus obtusus Dujardin, 1845; Is - Gnathia pantherina Smit et Basson, 2002; Ki Trypanosoma haploblephari Yeld et Smit, 2006

Haploblepharus pictus (Müller et Henle): Ki - Trypanosoma haploblephari Yeld et Smit, 2006

Poroderma africanum (Gmelin): Co - Pandarus cranchi Leach, 1819

Poroderma pantherium (Müller et Henle): Is - Gnathia pantherina Smit et Basson, 2002

Scyliorhinidae gen. sp.: Tr - Probolitrema richiardii (López, 1888)

Scyliorhinus sp.: Co-Achtheinus pinguis Wilson, 1912

Fa mily: Triakidae
Galeorhinus galeus (Linnaeus): Co - Achtheinus pinguis Wilson, 1912; Kroyeria rhophemophaga Deets, 1994 (nomen nudum); Pandarus bicolor Leach, 1816

Mustelus canis (Mitchill): Co - Achtheinus dentatus Wilson, 1911

Mustelus mosis Hemprich et Ehrenberg: Co - Achtheinus dentatus Wilson, 1911; Pseudopandarus gracilis Kirtisinghe, 1950; P. longus (Gnanamuthu, 1951)

Mustelus mustelus (Linnaeus): Co - Achtheinus oblongus Wilson, 1908; A pinguis Wilson, 1912; Lernaeopoda galei Krøyer, 1837; Nesippus orientalis Heller, 1865; Tripaphylus beatricae Dippenaar, 2018

Mustelus palumbes Smith: $\mathrm{Ce}$ - Calliobothrium euzeti Bernot, Caira et Pickering, 2015; Symcallio peteri Bernot, Caira et Pickering, 2015; Co - Kroyeria lineata van Beneden, 1853; Tripaphylus benzi Dippenaar, 2018; T. hoi Dippenaar, 2018

Mustelus sp.: Co - Achtheinus dentatus Wilson, 1911; A. oblongus Wilson, 1908

Scylliogaleus queketti Boulenger: $\mathrm{Ce}-$ Nybelinia africana Dollfus, 1960

F a mily: Hemigaleidae

Hemipristis elongata (Klunzinger): Co - Tripaphylus lewisi Dippenaar, 2018

F a mily: Sphyrnidae

Sphyrna lewini (Griffith et Smith): Ce - Heteronybelinia yamagutii (Dollfus, 1960); Co - Eudactylina aspera Heller, 1865; Kroyeria sphyrnae Rangnekar, 1957; Kroeyerina scottorum Cressey, 1972; Nemesis sp. 1; Nemesis sp. 3; Nesippus orientalis Heller, 1865; Pandarus sp. 2; Pannosus japonicas (Shiino, 1960); Tripaphylus vaissierei (Delamare Deboutteville et Nuñes-Ruivo, 1954); $\mathrm{Tr}$ - Multicalyx cristata Faust et Tang, 1936

Sphyrna mokarran (Rüppell): Ce - Heteronybelinia heteromorphi Palm, 1999; Co - Eudactylina pollex Cressey, 1967; Kroyeria gemursa Cressey, 1967; Nesippus crypturus Heller, 1868; N. orientalis Heller, 1868

Sphyrna zygaena (Linnaeus): Co - Achtheinus dentatus Wilson, 1911; Rangnekar, 1957; Nesippus crypturus Heller, 1868; N. orientalis Heller, 1868; Pandarus cranchi Leach, 1819

Sphyrna sp.: Co - Pandarus cranchi Leach, 1819

"hammerhead shark": Co - Pandarus cranchi Leach, 1819

F a mily: Carcharhinidae

Carcharhinus amboinensis (Müller et Henle): Co - Kroyeria procerobscena Deets, 1994 (nomen nudum); Kr. carchariaeglauci Hesse, 1879; Paralebion elongatus Wilson, 1911

Carcharhinus brachyurus (Günther): Co - Nesippus orientalis Heller, 1865;

Carcharhinus brevipinna (Müller et Henle): Co - Kroyeria deetsi Dippenaar, Benz et Olivier, 2000; Kroyeria sp.; Nesippus crypturus Heller, 1868; N. orientalis Heller, 1868; Nemesis sp. 1; Nemesis sp. 2; Nemesis sp. 5

Carcharhinus leucas (Müller et Henle): Ce - Heteronybelinia estigmena (Dollfus, 1960); Nybelinia africana Dollfus, 1960; Poecilancistrium caryophyllum (Diesing, 1850); Pseudogrillotia perelica (Shuler, 1938); Co - Achtheinus dentatus Wilson, 1911; Caligus coryphaenae Steenstrup et Lütken, 1861; Kroyeria carchariaeglauci Hesse, 1878; K. procerobscena Deets, 1994 (nomen nudum); Lepeophtheirus longispinosus Wilson, 1908; L. natalensis Kensley et Grindley, 1973; Nesippus crypturus Heller, 1868; N. orientalis Heller, 1868; Pandarus carcharini Ho, 1963; Paralebion elongatus Wilson, 1911

Carcharhinus limbatus (Müller et Henle): Ce - Heteronybelin- 
ia estigmena (Dollfus, 1960); H. robusta (Linton, 1890); Nybelinia scoliodoni (Vijayalakshmi, Vijayalakshmi et Gangdharam, 1996); Co - Achtheinus dentatus Wilson, 1911; Eudactylina aspera Heller, 1865; Kroyeria longicauda Cressey, 1970; Lepeophtheirus longispinosus Wilson, 1908; Nemesis sp. 3; Nesippus crypturus Heller, 1868; N. orientalis Heller, 1868; Paralebion elongatus Wilson, 1911

Carcharhinus longimanus (Poey): Co - Pandarus cranchi Leach, 1819

Carcharhinus melanopterus (Quoy et Gaimard): Ce - Paraorygmatobothrium angustum (Linton, 1889)

Carcharhinus obscurus (Lesueur): $\mathrm{Ce}$ - Nybelinia africana Dollfus, 1960; Co - Achtheinus dentatus Wilson, 1911; Alebion carchariae Krøyer, 1863; A. gracilis Wilson, 1905; Alebion sp.; Caligus coryphaenae Steenstrup et Lütken, 1861; Eudactylina dollfusi Brian, 1924; Kroyeria decepta Deets, 1994 (nomen nudum); Nemesis sp. 3; Nemesis sp. 4; Pandarus smithii Rathbun, 1886; Paralebion elongatus Wilson, 1911; Pseudopandarus longus (Gnanamuthu, 1951); Tripaphylus elongatus (Wilson, 1932); Mo - Dermophthirius carcharhini MacCallum, 1926

Carcharhinus plumbeus (Nardo): $\mathrm{Ce}-$ Pseudogrillotia perelica (Shuler, 1938); Co - Eudactylina dollfusi Brian, 1924; Nesippus nana Cressey, 1970

Carcharhinus sealei (Pietschmann): Co - Achtheinus dentatus Wilson, 1911; Nemesis sp. 3; Pseudopandarus longus (Gnanamuthu, 1951)

Carcharhinus sp.: Co - Alebion carchariae Krøyer, 1863; Pandarus bicolor Leach, 1816; Pandarus smithii Rathbun, 1886

Galeocerdo cuvier (Péron et Lesueur): Co - Eudactylina pusilla Cressey, 1967; Kroyeria dispar Wilson, 1935; K. papillipes Wilson, 1932; Nesippus crypturus Heller, 1868; N. tigris Cressey, 1967; Phyllothyreus cornutus (Milne-Edwards, 1840)

Prionace glauca (Linnaeus): Ce - Nybelinia schmidti Palm, 1999; Co - Anthosoma crassum (Abildgaard, 1794); Dinemoura latifolia (Steenstrup et Lütken, 1861); Echthrogaleus coleoptratus (Guérin-Méneville, 1837); Kroyeria carchariaeglauci Hesse, 1878; Nemesis robusta (van Beneden, 1851); Pandarus smithii Rathbun, 1886

Prionace sp.: Co - Dinemoura latifolia (Steenstrup et Lütken, 1861)

Rhizoprionodon acutus (Rüppell): Co - Achtheinus pinguis Wilson, 1911; Lernaeopoda galei Krøyer, 1837; Pseudopandarus longus (Gnanamuthu, 1951)

Scoliodon laticaudus Müller et Henle: Co - Pandarus smithii Rathbun, 1886

Scoliodon sp.: Co - Achtheinus dentatus Wilson, 1911

Triaenodon obesus (Rüppell): Co - Pseudopandarus longus (Gnanamuthu, 1951)

"grey shark": Co - Pandarus bicolor Leach, 1816

"shark": Co - Euryphorus brachypterus (Gerstaecker, 1853); Achtheinus dentatus Wilson, 1911; A. pinguis Wilson, 1912; Alebion carchariae Krøyer, 1863; Caligus coryphaenae Steenstrup et Lütken, 1861

\section{CONCLUSIONS}

Marine parasitology has a long history in South Africa dating back almost two centuries. However, information on the parasite fauna was gathered through opportunistic findings, while large-scale systematic attempts on certain host groups or biogeographical regions are lacking. Scientists also displayed a bias towards certain groups of parasitic organisms (e.g. parasitic copepods), while others remained undetected and neglected. This is especially notable for chondrichthyans, a very diverse host group in South Africa. With roughly 200 species of elasmobranchs and few holocephalans known from this biogeographical region (Ebert and van Hees 2015), only a small proportion of species has been observed for parasites. In order to rigorously assess the diversity of chondrichthyan parasites, dedicated biodiversity efforts are essential, with a particular focus on under-represented hosts and regions.

At present, knowledge on the parasites of cartilaginous fishes in South Africa is fragmentary and incomplete. In addition, the chondrichthyan fauna of South Africa contains a high degree of endemism, with approximately $13 \%$ of species only present in these waters. Information on parasite assemblages from endemic hosts would significantly expand our knowledge on the co-evolution of hosts and parasites in this region and their host-parasite interactions. Advancement in knowledge on the biology (including parasitism) of endemic host species could also contribute to conservation efforts helping to sustain the unique marine fauna present in South Africa. Information on a molecular level may be used to highlight the phylogenetic relationships of parasites from Temperate Southern Africa (sensu Spalding et al. 2007) and those of adjacent biogeographical provinces (e.g. Temperate South America or Western Indo-Pacific; sensu Spalding et al. 2007).

One of the biggest obstacles in marine parasitological research in South Africa, however, seems to be the lack of expertise and systematists able to assess the diversity of parasitic groups, especially protists, helminths, myxozoans and hirudineans. In order to resolve this issue, educational programs to train future taxonomists and systematists should be implemented. Another major obstacle scientists in this line of research are faced with is the sampling of chondrichthyans for parasitological studies. A total of $29 \%$ of all chondrichthyan species present in South African waters, including $13 \%$ of the endemic species, are placed in the three highest categories (i.e. vulnerable, endangered, critically endangered) in the International Union for the Conservation of Nature (IUCN) Red List of Threatened Species (Ebert and van Hees 2015).

Apart from certain ectoparasitic groups found on outer surfaces of the host, the assessment of endoparasites requires lethal-sampling of host individuals. Obtaining permits to sample chondrichthyan species solely for the purpose of parasitological work is unlikely being approved. An alternative for this dilemma is to form active collaborations with foundations and organisations focused on chondrichthyan conservation. The host specimen as such represents a whole ecosystem for parasites. For this reason, some scientists and especially parasitologists argue that conservation efforts should also be expanded from the threatened host species to include its parasites. Implementing parasites as conservation targets and learning more about the unique host-parasite interactions and life histories, we would gain insights into the biology of the host and ultimately help to preserve the biodiversity by protecting the threatened host species and a wide array of parasite species, which may face extinction together with their host species. This study 
along with previous reviews (Smit and Hadfield 2015, Reed 2015, Van As 2015) and faunal checklists (e.g. Van As and Basson 1984, Oldewage and Avenant-Oldewage 1993, Dippenaar et al. 2004) illustrates that South Africa boasts a prodigious fauna in both marine and freshwater systems. However, even after centuries of research, the fauna still remains insufficiently explored. Documenting this neglected fauna and describing species new to science could tremendously advance scientific research in South Africa and would also provide opportunities for younger generations of South Africans to pursue a scientific career.

Acknowledgements. This study was financed by the postdoctoral fellowship of the principle author from North-West University.

\section{REFERENCES}

Aвbotт L.M., Caira J.N. 2014: Morphology meets molecules: a new genus and two new species of diphyllidean cestodes from the yellowspotted skate, Leucoraja wallacei, from South Africa. J. Parasitol. 100: 323-330.

Adamson M., Deets G., Benz G. 1987: Description of male and redescription of female Phlyctainophora squali Mudry and Dailey, 1969 (Nematoda; Dracunculoidea) from elasmobranchs. Can. J. Zool. 65: 3006-3010.

Alves P.V., Vieira F.M., Santos C.P., Scholz T., Luque J.L. 2015: A checklist of the Aspidogastrea (Platyhelminthes: Trematoda) of the world. Zootaxa 3918: 339-396.

Aragort W., Alvarez F., Iglesias R., Leiro J., Sanmartín M. 2002: Histodytes microocellatus gen. et sp. nov. (Dracunculoidea: Guyanemidae), a parasite of Raja microocellata on the European Atlantic coast (north-western Spain). Parasitol. Res. 88: 932-940.

Aragort W., Alvarez M., Leiro J., Sanmartín M. 2005 : Blood protozoans in elasmobranchs of the family Rajidae from Galicia (NW Spain). Dis. Aquat. Org. 65: 63-68.

Avenant-Oldewage A. 1994: A new species of Argulus from Kosi Bay, South Africa and distribution records of the genus. Koedoe 37: 89-95.

Avenant-Oldewage A., Oldewage W. 1995: A new species of Argulus (Crustacea: Branchiura) from a bony fish in Algoa Bay, South Africa. Afr. Zool. 30: 197-199.

Awerinzew S. 1925: Über eine neue Art von parasitären Tricladen. Zool. Anz. 64: 17-21.

BAll I.R., KHAN R. 1976: On Micropharynx parasitica Jägerskiöld, a marine planarian ectoparasitic on thorny skate, Raja radiata Donovan, from the North Atlantic Ocean. J. Fish Biol. 8: 419-426.

BARNARD K. 1948: XVIII. New records and descriptions of new species of parasitic Copepoda from South Africa. J. Nat. Hist. 1: 242-254.

BARNARD K.H. 1936: Isopods collected by the R.I.M.S. "Investigator". Rec. Ind. Mus. 38: 147-191.

Barnard K.H. 1955a: South African parasitic Copepoda. Ann. S. Afr. Mus. 41: 223-344.

BARnARD K.H. 1955b: Additions to the fauna-list of South African Crustacea and Pycnogonida. Ann. S. Afr. Mus. 43: 1-107.

BAsson L., VAN As J., Fishelson L. 1990: A new species of Trichodina (Ciliophora: Peritrichia) from the intestine of the surgeonfish Acanthurus xanthopterus. Int. J. Parasitol. 20: 785-787.

Baylis H.A. 1933: XXXIII. On the nematode genus Proleptus. J. Nat. Hist. 12: 325-335.

van Beneden P.-J. 1861: Recherches sur la faune littorale de Belgique, Crustacés. Mém. Acad. Roy. Sci. Lett. Belg. 33: 1-180.

Bennett M., Heupel M., Bennett S., Parker A. 1997: Sheina orri (Myodocopa: Cypridinidae), an ostracod parasitic on the gills of the epaulette shark, Hemiscyllium ocellatum (Elasmobranchii: Hemiscyllidae). Int. J. Parasitol. 27: 275-281.

Benz G., Bullard S. 2004: Metazoan parasites and associates of chondrichthyans with emphasis on taxa harmful to captive hosts. In: M. Smith, D. Thoney and R. Hueter (EDS.), The Elamobranch Husbandry Manual: Captive Care of Sharks, Rays, and their Relatives. Ohio Biological Survey, Columbus, pp. 325-416.
Bernot J.P., Caira J.N., Pickering M. 2015: The dismantling of Calliobothrium (Cestoda: Tetraphyllidea) with erection of Symcallio n. gen. and description of two new species. J. Parasitol. 101: $167-181$.

Beveridge I., Haseli M., Ivanov V., Menoret A., SchaeffNER B. 2017: Trypanorhyncha Diesing, 1863. In: J.N. Caira and K. Jensen (EDS.), Planetary Biodiversity Inventory (2008-2017): Tapeworms from Vertebrate Bowels of the Earth. Natural History Museum, University of Kansas, Lawrence, pp. 401-429.

Beverley-Burton M., Chisholm L.A., Allison F.R. 1993: The species of Callorhynchicola Brinkmann (Monogenea: Chimaericolidae) from Callorhinchus spp. (Chimaeriformes: Callorhinchidae): adult morphology and the larval haptor. Syst. Parasitol. 24: 201-215.

Beverley-Burton M., Chisholm L.A., Last P. 1991: Two new species of Chimaericola Brinkmann (Monogenea: Chimaericolidae) from Hydrolagus spp. (Chimaeriformes: Chimaeridae) in the Pacific. Syst. Parasitol. 18: 59-66.

Bilqees F.M., Khan A. 2005: Two new helminth parasites from Pakistan, with redescription of the acanthocephalan Centrorhynchus fasciatum (Westrumb, 1821). Pak. J. Zool. 37: 257.

BIRD P. 1981: The occurrence of Cirolana borealis (Isopoda) in the hearts of sharks from Atlantic coastal waters of Florida. Fish. Bull. - United States 79: 376-383.

Boeger W.A., Kritsky D.C. 2001: Phylogenetic relationships of the Monogenoidea. Systematics Association Special Volume 60: 92-102.

Bousfield E.L. 1987: Amphipod parasites of fishes of Canada. Can. Bull. Fish. Aquat. Sci., Vol. 217, Department of Fisheries and Oceans, Ottawa, $37 \mathrm{pp}$.

Branch G., Griffiths C.L., Branch M.L., Beckley L.E. 2016: Two Oceans: A Guide to the Marine Life of Southern Africa, Vol 4. Struik Nature, Cape Town, 464 pp.

BRAY R.A. 1984: Some helminth parasites of marine fishes and cephalopods of South Africa: Aspidogastrea and the digenean families Bucephalidae, Haplosplanchnidae, Mesometridae and Fellodistomidae. J. Nat. Hist. 18: 271-292.

BRAY R.A. 1985: Some helminth parasites of marine fishes of South Africa: families Gorgoderidae, Zoogonidae, Cephaloporidae, Acanthocolpidae and Lepocreadiidae (Digenea). J. Nat. Hist. 19: 377-405.

BRAY R.A. 1986: Some helminth parasites of marine fishes of South Africa: families Enenteridae, Opistholebetidae and Pleorchiidae (Digenea). J. Nat. Hist. 20: 471-488.

BRAY R.A. 1987: Some helminth parasites of marine fishes of South Africa: family Opecoelidae (Digenea). J. Nat. Hist. 21: 10491075.

BRAY R.A. 1990: Hemiuridae (Digenea) from marine fishes of the southern Indian Ocean: Dinurinae, Elytrophallinae, Glomericirrinae and Plerurinae. Syst. Parasitol. 17: 183-217.

BRAY R.A. 1991: Hemiuridae (Digenea) from marine fishes of the southern Indian Ocean: Genus Lecithochirium Lühe, 1901 (Lecithochiriinae). Syst. Parasitol. 18: 193-219.

BRAY R., CRIBB T. 2003: The digeneans of elasmobranchs - distribution and evolutionary significance. In: C. Combes and J. Jourdane (EDS.), Taxonomie, Écologie et Évolution des Métazoires 
Parasites: Livre Hommage à Louis Euzet. PUP, Perpignan, pp. 67-96.

BRIGGS J.C. 1995: Global biogeography, Vol 14. Developments in Paleontology and Stratigraphy. Elsevier, Amsterdam, $451 \mathrm{pp}$.

BrusCA R.C. 1981: A monograph on the Isopoda Cymothoidae (Crustacea) of the eastern Pacific. Zool. J. Linn. Soc. 73: 117-199.

Bullard S.A., DippenaAr S.M. 2003: Branchotenthes robinoverstreeti $\mathrm{n}$. gen. and $\mathrm{n}$. sp. (Monogenea: Hexabothriidae) from gill filaments of the bowmouth guitarfish, Rhina ancylostoma (Rhynchobatidae), in the Indian Ocean. J. Parasitol. 89: 595-601.

Bullard S.A., Dippenaar S.M., Hoffmayer E.R., Benz G.W. 2004: New locality records for Dermophthirius carcharhini (Monogenea: Microbothriidae) and Dermophthirius maccallumi and a list of hosts and localities for species of Dermophthirius. Comp. Parasitol. 71: 78-80.

Bunkley-Williams L., Williams E.H. 1998: Isopods associated with fishes: a synopsis and corrections. J. Parasitol. 84: 893-896.

Burreson E.M. 1989: Hematozoa of fishes from Heron Island, Australia, with the description of two new species of Trypanosoma. Aust. J. Zool. 37: 15-23

Bychowsky B.E. 1957: Monogenetic Trematodes: Their Systematics and Phylogeny. Izdat. Akademii Nauk SSSR, Moscow, 509 pp. (In Russian.)

Bykhovskaya-Pavlovskaya I., Gusev A., Dubinina N., Izyumova T., Smirnova I., Sokolovskaya G., Shtein G., Shulman S., Epshtein V. 1964: Key to the Parasites of the Freshwater Fishes of the USSR. English translation: Israel Program for Scientific Translations, Jerusalem: 919 pp.

Caira J.N., Healy C.J. 2004: Elasmobranchs as hosts of metazoan parasites. In: J.C. Carrier and J.A. Musick and M.R. Heithaus (EDS.), Biology of Sharks and their Relatives. CRC Press, Boca Raton, Florida, pp. 523-551.

Caira J., Healy C., Jensen K. 2012: An updated look at elasmobranchs as hosts of metazoan parasites. In: J.C. Carrier, J.A. Musick and M.R. Heithaus (EDS.), Biology of Sharks and Their Relatives, Second Edition. CRC Press, Boca Raton, Florida, pp. 547-578.

Caira J.N., Jensen K. (Eds.) 2017: Planetary Biodiversity Inventory (2008-2017): Tapeworms from Vertebrate Bowels of the Earth, Special Publication No. 25. Natural History Museum, University of Kansas, Lawrence, 463 pp.

Caira J.N., Pickering M., Schulman A.D., Hanessian N.J. 2013a: Two new species of Echinobothrium (Cestoda: Diphyllidea) from batoids off South Africa. Comp. Parasitol. 80: 22-32.

Caira J.N., Rodriguez N., Pickering M. 2013b: New African species of Echinobothrium (Cestoda: Diphyllidea) and implications for the identities of their skate hosts. J. Parasitol. 99: 781-788.

Chabaud A. 1960: Deux nématodes parasites de serpents malgaches. Mém. l'Inst. Scient. Madagascar 14: 95-103.

Cheung P. 1993: Parasitic diseases of elasmobranchs. In: M.K. Stoskopf (ED.), Fish Medicine. Saunders, Philadelphia, pp. 782 807.

Ching H., Parker L. 1983: Report of water mite larvae in the esophagus and stomach walls of mountain whitefish in British Columbia. Proc. Helminthol. Soc. Wash. 50: 325-329.

Chisholm L.A., Whittington I.D. 1998: Morphology and development of the haptors among the Monocotylidae (Monogenea). Hydrobiologia 383: 251.

Compagno L. 1999: An overview of chondrichthyan systematics and biodiversity in southern Africa. Trans. Roy. Soc. South Afr 54: $75-120$.

Compagno L.J., Ebert D.A., Smale M.J. 1989: Guide to the Sharks and Rays of Southern Africa. Struik Publishers, Cape Town, $160 \mathrm{pp}$.

Cressey R.F. 1967a: Revision of the family Pandaridae (Copepoda: Caligoida). Proc. U.S. Nat. Mus. 121: 1-133.

Cressey R.F. 1967b: Caligoid copepods parasitic on sharks of the Indian Ocean. Proc. U.S. Nat. Mus. 121: 1-21.
Cressey R.F. 1972: The Genus Argulus (Crustacea: Branchiura) of the United States. U. S. Environmental Protection Agency, Washington, D.C., 14 pp.

Cressey R.F. 1978: Marine Flora and Fauna of the Northeastern United States: Crustacea: Branchiura. U. S. Department of Commerce, National Oceanic and Atmospheric Administration, National Marine Fisheries Service, Washington D.C., 10 pp.

Cribi T., Bray R., Littlewood D. 2001: The nature and evolution of the association among digeneans, molluscs and fishes. Int. J. Parasitol. 31: 997-1011.

Crompton D.W.T., Nickol B.B. (Eds.) 1985: Biology of the Acanthocephala. Cambridge University Press, Cambridge, $519 \mathrm{pp}$.

DARWIN C. 1851: A Monograph on the Sub-class Cirripedia, with Figures of All the Apecies. Ray society, London, $400 \mathrm{pp}$.

Davies A., Ball S. 1993: The biology of fish coccidia. Adv. Parasitol. 32: 294-366.

Davies A., Smit N. 2001: The life cycle of Haemogregarina bigemina (Adeleina: Haemogregarinidae) in South African hosts. Folia Parasitol. 48: 169-177.

Davies A.J., Hosein S., Merrett N.R. 2012: Haematozoans from deep water fishes trawled off the Cape Verde Islands and over the Porcupine Seabight, with a revision of species within the genus Desseria (Adeleorina: Haemogregarinidae). Folia Parasitol. 59: 1-11.

Dentzien-Dias P.C., Poinar JR G., De Figueiredo A.E.Q., PaCheco A.C.L., Horn B.L., Schultz C.L. 2013: Tapeworm eggs in a 270 million-year-old shark coprolite. PLoS ONE 8: e55007.

Diebakate C., Raibaut A., Kabata Z. 1997: Thamnocephalus cerebrinoxius n.g., n. sp. (Copepoda: Sphyriidae), a parasite in the nasal capsules of Leptocharias smithii (Müller \& Henle, 1839) (Pisces: Leptochariidae) off the coast of Senegal. Syst. Parasitol. 38: 231-235.

DiKGALE M., M. D.S. 2010: Copepod parasites from elasmobranchs off the coast of South Africa. J. S. Afr. Vet. Assoc. 81: 185.

Dippenaar S., van Tonder R., Wintner S., Zungu P. 2008: Spatial distribution of Nemesis lamna Risso 1826 (Copepoda: Siphonostomatoida: Eudactylinidae) on the gills of white sharks Carcharodon carcharias off KwaZulu-Natal, South Africa. Afr. J. Mar. Sci. 30: 143-148.

DippenaAR S.M. 2004: Reported siphonostomatoid copepods parasitic on marine fishes of southern Africa. Crustaceana 77: 1281-1328.

DipPENAAR S.M. 2009: Estimated molecular phylogenetic relationships of six siphonostomatoid families (Copepoda) symbiotic on elasmobranchs. Crustaceana 82: 1547-1567.

DippenaAR S.M. 2012: A redescription of Pseudocharopinus pteromylaei Raibaut et Essafi, 1979 (Siphonostomatoida: Lernaeopodidae) collected from the South African east coast. Folia Parasitol. 59: 216-220.

DippenaAR S.M. 2016: Schistobrachia kabata sp. nov. (Siphonostomatoida: Lernaeopodidae) from rajiform hosts off South Africa. Zootaxa 4174: 104-113.

DippenaAR S.M. 2017: Trebius benzi n. sp. (Siphonostomatoida: Trebiidae) infecting Squalus acutipinnis Regan off South Africa. Syst. Parasitol. 94: 91-96.

DippenaAR S.M. 2018: Description of four new species and a revision of the genus Tripaphylus Richiardi in Anonymous, 1878 (Copepoda: Siphonostomatoida: Sphyriidae). Syst. Parasitol. 95: 173-200.

Dippenaar S.M., Benz G.W., Olivier P.A.S. 2000: Kroyeria deetsi n. sp. (Kroyeriidae: Siphonostomatoida), a parasitic copepod infecting gills of spinner sharks, Carcharhinus brevipinna (Müller \& Henle, 1839), in the Indian Ocean. Afr. Zool. 35: $185-192$.

DippenaAR S.M., JordaAn A. 2015: How females of Achtheinus spp. (Pandaridae: Siphonostomatoida) attach to their elasmobranch hosts with notes on their effects on the hosts' fins. Folia Parasitol. 62: 1-5. 
DippenaAR S.M., JordaAn B.P. 2006: Nesippus orientalis Heller, 1865 (Pandaridae: Siphonostomatoida): descriptions of the adult, young and immature females, a first description of the male and aspects of their functional morphology. Syst. Parasitol. 65: 27-41.

DippenaAR S.M., JordaAn B.P. 2007: New host and geographical records of siphonostomatoid copepods associated with elasmobranchs off the KwaZulu-Natal coast, South Africa. Onderstepoort J. Vet. Res. 74: 169-175.

DippenaAr S.M., JordaAn B.P. 2012: Notes on the morphology and ecology of the adult females of Nesippus species (Siphonostomatoida: Pandaridae) with a key for identification. Zootaxa 3170: $18-30$.

DippenaAr S.M., Lebepe M. 2013: Two new species of Pupulina van Beneden, 1892 (Copepoda: Siphonostomatoida: Caligidae) from mobulid rays off South Africa. Syst. Parasitol. 85: 27-35.

Dippenaar S.M., Mathibela R.B., Bloomer P. 2010: Cytochrome oxidase I sequences reveal possible cryptic diversity in the cosmopolitan symbiotic copepod Nesippus orientalis Heller, 1865 (Pandaridae: Siphonostomatoida) on elasmobranch hosts from the KwaZulu-Natal coast of South Africa. Exp. Parasitol. 125: 42-50

Dippenaar S.M., Molele R.A. 2015: Siphonostomatoid copepods infecting Squalus acutipinnis Regan, 1908 off South Africa. Afr. J. Mar. Sci. 37: 605-608.

Dippenaar S.M., Olivier P.A.S. 1999a: New morphological information of the parasitic copepod Kroyeria dispar Wilson, 1935 (Copepoda: Kroyeriidae) from the east coast of South Africa. South Afr. J. Zool. 34: 125-129.

Dippenaar S.M., Olivier P.A.S. 1999b: Additional features of Kroyeria dispar Wilson, 1935 (Kroyeriidae, Copepoda) from the tiger shark Galeocerdo cuvieri. J. S. Afr. Vet. Assoc. 70: 43.

Dippenaar S.M., Olivier P.A.S., Benz G.W. 2000: Kroyeria sp. (Kroyeriidae: Siphonostomatoida), a parasitic copepod infesting gills of spinner sharks (Carcharhinus brevipinna (Müller \& Henle, 1838)) in the Indian Ocean. Abstract. J. S. Afr. Vet. Assoc. 71: 135 .

Dippenaar S.M., Olivier P.A.S., Benz G.W. 2001: Kroyeria sphyrnae Rangnekar, 1957 (Copepoda, Siphonostomatoida, Kroyeriidae): first description of the male, supplementary remarks on the female, A new geographic record for the species, and a key to Kroyeria males. Crustaceana 74: 883-894.

Dippenaar S.M., Olivier P.A.S., Benz G.W. 2004: Schistobrachia jordaanae n. sp. (Copepoda: Siphonostomatoida: Lernaeopodidae) from gill filaments of a diamond ray (Gymnura natalensis) captured in the Indian Ocean and a key to species of Schistobrachia, Dendrapta and Brianella. J. Parasitol. 90 481-484.

DippenaAR S.M., van Tonder R.C., Wintner S.P. 2009: Is there evidence of niche restriction in the spatial distribution of $\mathrm{KrO}-$ yeria dispar Wilson, 1935, K. papillipes Wilson, 1932 and Eudactylina pusilla Cressey, 1967 (Copepoda: Siphonostomatoida) on the gill filaments of tiger sharks Galeocerdo cuvier off KwaZulu-Natal, South Africa? Hydrobiologia 619: 89-101.

Dyкоvé I., Lом J. 1981: Fish coccidia: critical notes on life cycles, classification and pathogenicity. J. Fish Dis. 4: 487-505.

Ebert D., van Hees K.E. 2015: Beyond jaws: rediscovering the 'lost sharks' of southern Africa. Afr. J. Mar. Sci. 37: 141-156.

Evdokimova E., Kuznetsova I., Stein G. 1969: [Parasitic ciliates of the family Urceolariidae (Peritricha, Mobilia) from some fish of the southwest Atlantic.] Zool. Zh. 48: 1451-1455. (In Russian.)

Fain A., Belpaire C. 1985: A new mite (Acari, Anoetidae) parasitising the gills of young eels Anguilla anguilla (L.). Bull. Ann. Soc. Roy. Belg. Entomol. 121: 285-292.

Fain A., Lambrechts L. 1985: A new anoetid mite parasitic in the swim-bladder of the aquarium fish Pangasius sutchi. Bull. Ann. Konink1. Belg. Veren. Entomol. 121: 119-126.

Fantham H.B. 1918: Some parasitic protozoa found in South African fishes and amphibians. S. Afr. J. Sci. 15: 337-338.
Fantham H. 1930: Some parasitic protozoa found in South Africa. S. Afr. J. Sci. 27: 376-390.

Ferreira M.L., Smit N.J., Davies A.J. 2012: Unusual haemogregarines parasitising intertidal teleosts from the subtropical east coast of South Africa, with the description of Haemogregarina kunegemina sp. nov. J. Mar. Biolog. Assoc. U.K. 92: 1209-1215.

Froese R., Pauly D. (Eds.) 2018: FishBase. World Wide Web electronic publication, www.fishbase.org, 6/2018.

Garner M. 2013: A retrospective study of disease in elasmobranchs. Vet. Pathol.50: 377-389.

Gibson D.I. 1976: Monogenea and Digenea of fishes. Discov. Rep. 36: 179-266.

Goertz C.E.C. 2004: Protozoal diseases of elasmobranchs. In: M. Smith, D. Warmolts, D. Thoney and R. Hueter (EDs.), The Elasmobranch Husbandry Manual: Captive Care of Sharks, Rays and their Relatives. Ohio Biological Survey, Columbus, pp. 417-426.

Golvan Y.J. 1959: Acanthocéphales du genre Corynosoma Lühe 1904, parasites de Mammifères d'Alaska et de Midway. Ann. Parasitol. Hum. Comp. 34: 288-321.

Golvan Y.J. 1961: Le phylum des Acanthocephala - Troisième note. La classe des Palaeacanthocephala (Meyer 1931) (à suivre). Ann. Parasitol. Hum. Comp. 36: 76-91.

Golvan Y.J. 1969: Systématique des Acanthocéphales (Acanthocephala Rudolphi 1801). Première partie. L'ordre des Palaeacanthocephala Meyer 1931. Premier fascicule: la super-famille des Echinorhynchoidea (Cobbold 1876) Golvan et Houin 1963, Vol 57. Éditions du Muséum, Paris, France, 373 pp.

Golvan Y.-J., Gracia-Rodrigo A., Diaz-Ungria C. 1964 Megapriapus ungriai (Gracia-Rodrigo 1960) n. gen. (Palaeacanthocephala) parasite d'une Pastenague d'eau douce du Vénézuéla (Potamotrygon hystrix). Ann. Parasitol. Hum. Comp. 39: 53-59.

Griffiths C.L., Robinson T.B., Lange L., Mead A. 2010: Marine biodiversity in South Africa: an evaluation of current states of knowledge. PLoS ONE 5: e12008.

HARDING J. 1966: Myodocopan ostracods from the gills and nostrils of fishes. In: H. Barnes (Ed.), Some Contemporary Studies in Marine Science. Allen and Unwin, London, pp. 369-374.

Hare G., Burt M. 1975: Abundance and population dynamics of parasites infecting Atlantic salmon (Salmo salar) in Trout Brook, New Brunswick, Canada. J. Fish. Brd. Can. 32: 2069-2074.

Hayes P.M., Lawton S.P., Smit N.J., Gibson W.C., Davies A.J. 2014: Morphological and molecular characterisation of a marine fish trypanosome from South Africa, including its development in a leech vector. Parasit. Vectors. 7: 50

Hayes P., Smit N., Davies A. 2007: Pathology associated with parasitic juvenile gnathiids feeding on the puffadder shyshark, Haploblepharus edwardsii (Voight). J. Fish Dis. 30: 55-58.

Hayes P.M., Smit N.J., Seddon A.M., Wertheim D.F., Davies A.J. 2006: A new fish haemogregarine from South Africa and its suspected dual transmission with trypanosomes by a marine leech. Folia Parasitol. 53: 241-248.

Heemstra P.C., Heemstra E. 2004: Coastal Fishes of Southern Africa. NISC (PTY) Ltd., Grahamstown, 512 pp.

Heupel M., Bennett M. 1999: The occurrence, distribution and pathology associated with gnathiid isopod larvae infecting the epaulette shark, Hemiscyllium ocellatum. Int. J. Parasitol. 29: 321-330.

HiCKLING C. 1963: On the small deep-sea shark Etmopterus spinax L., and its cirripede parasite Anelasma squalicola (Lovén). Zool. J. Linn. Soc. 45: 17-24.

Hoggarth D.D. 1990: The effects of parasitism by the rhizocephalan, Briarosaccus callosus Boschma on the lithodid crab, Paralomis granulosa (Jacquinot) in the Falkland Islands. Crustaceana 59: $156-170$.

Hurley D.E. 1961: A checklist and key to the Crustacea Isopoda of New Zealand and Subantarctic Islands. Trans. Roy. Soc. N. Z. (Zool.) 1: 259-292.

JÄGERSKIÖLD L.A. 1896: Über Monostomum lacteum n. sp. Zoologische Studien, Festschrift Wilhelm Lilljeborg zum Achtigsten Geburtstag Gewidmet von Swedischen Zoologen, pp. 165-177 
Kabata Z. 1970: Crustacea as enemies of fishes. In: S.F. Snieszko and H.R. Axelrod (EDs.), Diseases of Fishes. T.F.H. Publications, New Jersey, 151-166 pp.

Karlsbakk E. 2004: A trypanosome of Atlantic cod, Gadus morhua L., transmitted by the marine leech Calliobdella nodulifera (Malm, 1863) (Piscicolidae). Parasitol. Res. 93: 155-158.

KensLey B. 1978: Guide to the Marine Isopods of southern Africa. South African Museum, Cape Town, 173 pp.

Kensley B., Grindley J.R. 1973: South African parasitic Copepoda. Ann. S. Afr. Mus. 62: 69-130.

Kent M., Margolis L., Corliss J. 1994: The demise of a class of protists: taxonomic and nomenclatural revisions proposed for the protest phylum Myxozoa Grassé, 1970. Can. J. Zool. 72 932-937.

Khan R. 1972: Developmental stages of Haemogregarina delagei Laveran and Mesnil in an elasmobranch, Raja radiata Donovan. Can. J. Zool. 50: 906-907.

Khan R., Barrett M., Murphy J. 1980: Blood parasites of fish from the northwestern Atlantic Ocean. Can. J. Zool. 58: 770-781.

Last P., Seret B., Naylor G. 2016a: A new species of guitarfish, Rhinobatos borneensis sp. nov. with a redefinition of the family-level classification in the order Rhinopristiformes (Chondrichthyes: Batoidea). Zootaxa 4117: 451-475.

Last P., White W., De Carvalho M., Seret B., Stehmann M., NAYLOR G. (EDs.) 2016b: Rays of the World. CSIRO Publishing, Melbourne, $800 \mathrm{pp}$.

Leach W. E. 1818: Cymothoadées. In: F. Cuvier (Ed.), Dictionnaire des Sciences Naturelles, vol. 12. Strasbourg et Levrault, Paris pp. 338-354.

Lebepe M.C., Dippenaar S.M. 2013: A report of symbiotic Siphonostomatoida (Copepoda) infecting mobulids (Rajiformes: Mobulidae) off the KwaZulu-Natal coast, South Africa. Afr. Zool. 48: $326-332$

LeUNG T.L. 2014: Evolution: how a barnacle came to parasitise a shark. Curr. Biol. 24: R564-R566.

Linton E. (ED.) 1924: Gyrocotyle plana sp. nov. with notes on South African cestodes of fishes. Cape Times Ltd., Cape Town, $27 \mathrm{pp}$.

Lom J. 1970: Trichodinid ciliates (Peritrichida: Urceolariidae) from some marine fishes. Folia Parasitol. 17: 113-125.

Lom J., Dykoví I. 1981: New species of the genus Eimeria (Apicomplexa: Coccidia) from marine fish. Z. Parasitenkd. 66: 207220.

Lом J., Dyкová I. 1992: Protozoan Parasites of Fishes. Elsevier Science Publishers, New York, 315 pp.

Long D.J., WAGGoner B.M. 1993: The ectoparasitic barnacle Anelasma (Cirripedia, Thoracica, Lepadomorpha) on the shark Centroscyllium nigrum (Chondrichthyes, Squalidae) from the Pacific sub-Antarctic. Syst. Parasitol. 26: 133-136.

Looss A. 1902: Die Distomen-Unterfamilie der Haploporinae. Arch. Parasitol. 6: 129-143.

Love M.S., Moser M. (EdS.) 1983: A checklist of parasites of California, Oregon, and Washington marine and estuarine fishes. U.S. Dept. of Commerce, National Oceanic and Atmospheric Administration, National Marine Fisheries Service, Seattle, 576 pp.

MaCCallum G.A. 1925: Eggs of a new species of nematoid worm from a shark. Proc. U.S. Nat. Mus. 67: 1-2.

Magro N., De Oliveira A., O’Dwyer L. 2016: First report and description of a Cyrilia sp. (Apicomplexa: Haemogregarinidae) from a freshwater cururu stingray Potamotrygon cf. histrix (Elasmobranchii: Potamotrygonidae), from the Amazon region, Brazil. J. Fish Dis. 39: 907-911.

Mangena T., JordaAn B.P., Dippenaar S.M. 2014: Phylogenetic relationships and genetic diversity of Nemesis Risso, 1826 species found on different elasmobranch host species off the KwaZulu-Natal coast, South Africa. Afr. J. Mar. Sci. 36: 163-173.

Manter H.W. 1955: Two new monogenetic trematodes from elephant fishes (Callorhynchus) from South Africa and New Zealand. Essays in the Natural Sciences in Honor of Captain Allan Hancock on the occasion of his birthday, July 26 1955: 211-220.
Meinert F.V.A. 1877: Crustacae Isopoda, Amphipoda et Decapoda Daninæ: fortegnelse over Danmarks Isopode, Amphipode og Decapode Krebsdyr. Naturhistorisk Tidsskrift 12: 465-512.

Mokumo P.J., DippenaAR S.M. 2015: Reports of Kroyeria species collected from South African waters with notes on the host-parasite associations. Afr. Zool. 50: 127-132.

Molnár K., Ostoros G., Dunams-Morel D., Rosenthal B.M. 2012: Eimeria that infect fish are diverse and are related to, but distinct from, those that infect terrestrial vertebrates. Infect. Genet. Evol. 12: 1810-1815.

Moore J.P. 1958: The leeches (Hirudinea) in the collection of the Natal Museum. Ann. Natal. Mus. 14: 303-340.

Moravec F. 2001: Trichinelloid Nematodes Parasitic in Cold-Blooded vertebrates. Academia, Praha, 429 pp.

Moravec F., Van As J.G., Dyková I. 2002: Proleptus obtusus Dujardin, 1845 (Nematoda: Physalopteridae) from the puffadder shyshark Haploblepharus edwardsii (Scyliorhinidae) from off South Africa. Syst. Parasitol. 53: 169-173.

Mueller J.F. 1932: Trichodina renicola (Mueller, 1931): A ciliate parasite of the urinary tract of Esox niger. Roosevelt Wildlife Annuals 3: 139-154.

Mueller J.F. 1938: A new species of Trichodina (Ciliata) from the urinary tract of the muskalonge, with a repartition of the genus. J. Parasitol. 24: 251-258

NaGasawa K. 1998: Predation by salmon sharks (Lamna ditropis) on Pacific salmon (Oncorhynchus spp.) in the North Pacific Ocean. NPAFC Bulletin 1: 419-433.

Nelson J.S., Grande T.C., Wilson M.V.H. 2016: Fishes of the World. $5^{\text {th }}$ Edition. John Wiley \& Sons, Hoboken, New Jersey, $752 \mathrm{pp}$.

Newman W., Zullo V., Withers T. 1969: Cirripedia. In: R. Moore (Ed.), Treatise on Invertebrate Paleontology, Part R, Arthropoda 4. University of Kansas and Geological Society of America, Lawrence, pp. 206-295.

von Ofenheim E. 1900: Über eine neue Distomidengattung. Z. Naturwissensch. 73: 145-186.

Okamura B., Gruhl A., Reft A.J. 2015: Cnidarian origins of the Myxozoa. In: B.G.B. Okamura and J.L. Bartholomew (EDs.), Myxozoan Evolution, Ecology and Development. Springer International Publishing AG, Cham, pp. 45-68.

OldewAGE W. 1992a: Occurrence and distribution of parasitic Copepoda (Crustacea) off the southern coast of South Africa. Afr. J. Wildl. Res. 22: 33-35.

Oldewage W. 1992b: Description of Perissopus oblongus (Wilson, 1908) (Copepoda, Pandaridae) from southern African sharks with a first description of the male. Crustaceana 63: 44-50.

OldewaGe W.H. 1992c: Aspects of the fine structure of female Dinemoura latifolia Steenstrup \& Lütken, 1861 (Copepoda: Pandaridae): an SEM Study. South Afr. J. Zool. 27: 6-10.

OldeWAGE W.H. 1993a: Occurrence and distribution of copepod fish parasites on the west coast of South Africa. J. of Afr. Zool. 107: 413-418.

Oldewage W.H. 1993b: A new species of Vanbenedenia Malm, 1860 (Copepoda: Lernaeopodidae) from the Southern Indian Ocean. Syst. Parasitol. 26: 137-140.

Oldewage W. 1995: Redescription of Alebion carchariae Kroyer, 1863 (Copepoda, Siphonostomatoida) from Isurus oxyrhynchus in South Africa. Crustaceana 68: 38-42.

Oldewage W.H., Avenant-Oldewage A. 1993: Checklist of the parasitic Copepoda (Crustacea) of African fishes. Zool. Dokumentatie 23: 1-28.

Oldewage W., Smale M. 1993: Occurrence of piscine parasitic copepods (Crustacea) on sharks taken mainly off Cape Recife, South Africa. South Afr. J. Mar. Sci. 13: 309-312.

Olivier P.A.S., Dippenaar S.M., Khalil L.F., Mokgalong N.M. 2000: Observations on a lesser-known monogenean, Udonella myliobati, from a copepod parasite, Lepeophtheirus natalensis, parasitising the spotted ragged-tooth shark, Carcharias taurus, from South African waters. Onderstepoort J. Vet. Res. 67: 135-140. 
Olson P., Cribb T., TKach V., Bray R., Littlewood D. 2003 Phylogeny and classification of the Digenea (Platyhelminthes: Trematoda) 1. Int. J. Parasitol. 33: 733-755.

Ommundsen A., Noever C., Glenner H. 2016: Caught in the act: phenotypic consequences of a recent shift in feeding strategy of the shark barnacle Anelasma squalicola (Lovén, 1844). Zoomorphology 135: 51-65.

O'Sullivan J., McConnaughey R., Huber M. 1987: A blood-sucking snail: the Cooper's nutmeg, Cancellaria cooperi Gabb, parasitises the California electric ray, Torpedo californica Ayres. Biol. Bull. 172: 362-366.

Palm H.W. 1999: Nybelinia Poche, 1926, Heteronybelinia gen. nov. and Mixonybelinia gen. nov. (Cestoda, Trypanorhyncha) in the collections of the Natural History Museum, London. Bull Nat. Hist. Mus. Zool. 65: 133-153.

Parukhin A.M. 1966: [On the species composition of the helminthfauna of fishes in the South Atlantic]. Mat. Nauch. Konf. Vsesoyuz. Obshch. Gel'mintologov: 219-222. (In Russian.)

Parukhin A. 1968: [Helminth fauna of fish in the South Atlantic.] In: V. Bodyanitski (Ed.), Biology of Seas. No. 14. Parasites of marine animals. Naukova Dumka, Kiev, pp. 96-113. (In Russian.)

Parukhin A., Tkachuk L. 1980: [New species of trematodes from fish in the Indian Ocean.] Nauch. Dokl. Vysshei Shkoly, Biol. Nauki 6: 41-44. (In Russian.)

Poddubnaya L.G., Reed C., Gibson D.I. 2015: The surface topography of Callorhynchocotyle callorhynchi (Manter, 1955) (Monogenea: Hexabothriidae), a parasite of the holocephalan fish Callorhinchus capensis. Parasitol. Res. 114: 3393-3399.

Randhawa H.S., Poulin R. 2010: Determinants of tapeworm species richness in elasmobranch fishes: untangling environmental and phylogenetic influences. Ecography 33: 866-877.

ReED C.C. 2015: A review of parasite studies of commercially important marine fishes in sub-Saharan Africa. Parasitology 142: 109-124.

Reinhard E.G. 1956: Parasitic castration of Crustacea. Exp. Parasitol. 5: 79-107.

Rodriguez N., Pickering M., CAIRA J.N. 2011: Echinobothrium joshuai $\mathrm{n}$. sp. (Cestoda: Diphyllidea) from the roughnose legskate, Cruriraja hulleyi (Rajiformes: Rajidae), off South Africa. Comp. Parasitol. 78: 306-311.

Rohde K. (ED.) 2005: Marine Parasitology. CSIRO Publishing, Melbourne $592 \mathrm{pp}$.

Rohde K., Littlewood D., Bray R. 2001: The Aspidogastrea, an archaic group of Platyhelminthes. In: D.T.J. Littlewood and R.A. Bray (EDS.), Interrelationships of the Platyhelminthes. Taylor and Francis, London, pp. 159-167.

Ross R.A. 1999: Freshwater Stingrays from South America. Aqualog Verlag, Rodgau, $64 \mathrm{pp}$.

Ruggiero M. A., Gordon D. P., Orrelt T. M., Bailly N., Bourgoin T., Brusca R. C., Cavalier-Smith T., Guiry M. D., Kirk P. M. 2015: A higher level classification of all living organisms. PLoS ONE 10: e0119248.

SAWYER R.T. 1986: Leech Biology and Behaviour: Feeding Biology, Ecology, and Systematics, Vol. 2. Oxford University Press, Oxford $420 \mathrm{pp}$.

Schlegel M., Lom J., Stechmann A., Bernhard D., Leipe D., Dyková I., Sogin M.L. 1996: Phylogenetic analysis of complete small subunit ribosomal RNA coding region of Myxidium lieberkuehni: evidence that Myxozoa are Metazoa and related to the Bilateria. Arch. Protistenkd. 147: 1-9.

Schramm M. 1989: Some trypanorhynch tapeworms found in marine fish. Naturalist 33: 22-26.

Schramm M. 1991: Grillotia perelica (Cestoda: Trypanorhyncha) plerocercoids in mullet (Pisces: Mugilidae) from estuaries in Transkei, southern Africa. South Afr. J. Mar. Sci. 11: 169-178.

Siddall M.E., Martin D.S., Bridge D., Desser S.S., Cone D.K. 1995: The demise of a phylum of protists: phylogeny of Myxozoa and other parasitic Cnidaria. J. Parasitol.: 961-967.
Smit N.J., Basson L. 2002: Gnathia pantherina sp. n. (Crustacea: Isopoda: Gnathiidae), a temporary ectoparasite of some elasmobranch species from southern Africa. Folia Parasitol. 49: $137-151$.

Smit N.J., Davies A.J. 1999: New host records for Haemogregarina bigemina from the coast of southern Africa. J. Mar. Biolog. Assoc. U. K. 79: 933-935.

Smit N.J., Davies A.J. 2001: An encapsulated haemogregarine from the evileye pufferfish in South Africa. J. Mar. Biolog. Assoc. U. K. 81: 751-754.

Smit N., Davies A. 2004: The curious life-style of the parasitic stages of gnathiid isopods. Adv. Parasitol. 58: 289-391.

Smit N.J., Davies A.J. 2006: Desseria zei sp. nov. (Adeleorina: Haemogregarinidae) infecting Zeus capensis from deep waters off the south and west coasts of South Africa. J. Mar. Biolog. Assoc. U.K. 86: 1477-1480.

Smit N.J., Hadfield K.A. 2015: Marine fish parasitology in South Africa: history of discovery and future direction. Afr. Zool. 50: 79-92.

Smit N.J., Van As J., Davies A.J. 2003: Taxonomic re-evaluation of the South African fish haemogregarine, Desseria fragilis. J. Parasitol. 89: 151-153.

Smit N.J., Van As L.L., Van As J.G. 2005: Redescription of Argulus multipocula Barnard, 1955 (Crustacea: Branchiura) collected on the west coast of SouthAfrica. Syst. Parasitol. 60: 75-80.

Spalding M.D., Fox H.E., Allen G.R., Daviddon N., Ferdaña Z.A., Finlayson M., Halpern B.S., Jorge M.A., Lombana A., Lourie S.A. 2007: Marine ecoregions of the world: a bioregionalisation of coastal and shelf areas. Bioscience 57: 573-583.

Utevsky A.Y. 2004: A new species of marine leeches (Hirudinea, Piscicolidae) from the coastal waters of South Africa. Vestn. Zool. 38: 79-83.

Utevsky A.Y. 2007: A new genus and species of marine fish leech (Annelida: Hirudinea: Piscicolidae) from South Africa. Afr. Invertebr. 48: 41-46.

VAder W., Romppainen K. 1986: Notes on Norwegian marine Amphipoda. 10. Scavengers and fish associates. Fauna Norv. series A 6: 3-8.

VAN As J.G. 2015: A brief history of freshwater fish parasitology in southern Africa. Afr. Zool. 50: 93-107.

VAN As J.G., BASSON L. 1984: Checklist of freshwater fish parasites from southern Africa. Afr. J. Wildl. Res. 14: 49-61.

VAn As J., Basson L. 1996: An endosymbiotic trichodinid, Trichodina rhinobatae sp. n. (Ciliophora: Peritrichia) found in the lesser guitarfish, Rhinobatos annulatus Smith, 1814 (Rajiformes: Rhinobatidae) from the South African Coast. Acta Protozool. 35: 61-67.

Van As J., Du Preez J., Brown L., Smit N. 2012: The Story of Life and the Environment, an African Perspective. Struik Nature, Cape Town, $456 \mathrm{pp}$.

Van As J., VAn As L.L. 2001: Argulus izintwala n. sp. (Crustacea: Branchiura) from Lake St Lucia, South Africa. Syst. Parasitol. 48: 75-79.

Van As J., Van Niekerk J., Olivier P. 1999: Description of the previously unknown male of Argulus kosus Avenant-Oldewage, 1994 (Crustacea: Branchiura). Syst. Parasitol. 43: 75-80.

Vaughan D.B., Chisholm L.A. 2010a: Heterocotyle tokoloshei sp. nov. (Monogenea, Monocotylidae) from the gills of Dasyatis brevicaudata (Dasyatidae) kept in captivity at Two Oceans Aquarium, Cape Town, South Africa: description and notes on treatment. Acta Parasitol. 55: 108-114.

Vaughan D.B., Chisholm L.A. 2010b: A new species of Neoheterocotyle Hargis, 1955 (Monogenea: Monocotylidae) from the gills of Rhinobatos annulatus Müller \& Henle (Rhinobatidae) off the southern tip of Africa. Syst. Parasitol. 77: 205-213.

Vaughan D., Chisholm L. 2011: Amendment of Pseudoleptobothrium Young, 1967 (Monogenea, Microbothriidae) with the description of Pseudoleptobothrium christisoni sp. nov. from the dermal denticles of Rhinobatos annulatus (Rhinobatidae) off the southern tip of Africa. Acta Parasitol. 56: 280-289. 
Vaughan D., Chisholm L., Christison K. 2008: Overview of South African Dendromonocotyle (Monogenea: Monocotylidae), with descriptions of 2 new species from stingrays (Dasyatidae) kept in public aquaria. Zootaxa 1826: 26-44.

Vaughan D., Christison K. 2012: Towards addressing the current state of confusion within the Hexabothriidae Price, 1942 (1908): Callorhynchocotyle Suriano \& Incorvaia, 1982 (Monogenea: Hexabothriidae) re-visited, with the preliminary evaluation of novel parameters for measuring haptoral armature of hexabothriids. Zootaxa 3229: 1-34.

Weaver H.J., Smales L.R. 2014: Two species of Acanthocephala (Rhadinorhynchidae and Transvenidae) from elasmobranchs from Australia. Comp. Parasitol. 81: 110-113.

Weigmann S. 2016: Annotated checklist of the living sharks, batoids and chimaeras (Chondrichthyes) of the world, with a focus on biogeographical diversity. J. Fish Biol. 88: 837-1037.

Whittington I.D., Cribb B.W., Hamwood T.E., Halliday J.A. 2000: Host-specificity of monogenean (platyhelminth) parasites: a role for anterior adhesive areas? Int. J. Parasitol. 30: 305-320.

Williams E.H., Bunkley-Williams L. 1996: Parasites of offshore big game fishes of Puerto Rico and the western Atlantic. University of Puerto Rico, Mayagüez 382 pp.

WiLsON C.B. 1902: North American parasitic copepods of the family Argulidae: with a bibliography of the group and a systematic review of all known species. Proc. U.S. Nat. Mus. 25: 635-742.

Wilson C.B. 1904: A new species of Argulus, with a more complete account of two species already described. Proc. U.S. Nat. Mus. 27: 627-655.
WiLson C.B. 1913: Crustacean parasites of West Indian fishes and land crabs, with descriptions of new genera and species. Proc. U.S. Nat. Mus. 44: 189-277.

Wilson C.B. 1923: New species of parasitic copepods from southern Africa. Medd. Göteborgs mus. Zool. avdelning 25: 1-11.

WoRMS EdITORIAL BOARD 2018: World Register of Marine Species. World Wide Web electronic publication, www.marinespecies.org, 6/2018.

Xavier R., Santos J.L., Veríssimo A. 2018: Phylogenetic evidence for an ancestral coevolution between a major clade of coccidian parasites and elasmobranch hosts. Syst. Parasitol. 95: 367-371.

Xu K., Song W., Warren A., Choi J.K. 2001: Trichodinid ectoparasites (Ciliophora: Peritrichida) of some marine fishes from coastal regions of the Yellow Sea and Bohai Sea. Syst. Parasitol. 50: 69-79.

Yano K., Musick J.A. 2000: The effect of the mesoparasitic barnacle Anelasma on the development of reproductive organs of deep-sea squaloid sharks, Centroscyllium and Etmopterus. Environ. Biol. Fishes 59: 329-339.

Yeld E.M. 2009: Parasite assemblages of three endemic catshark species from the west and south coasts of South Africa. University of Cape Town, Ph.D. Thesis, 175 pp.

Yeld E., Smit N. 2006: A new species of Trypanosoma (Kinetoplastida: Trypanosomatidae) infecting catsharks from South Africa. J. Mar. Biolog. Assoc. U.K. 86: 829-833.

Cite this article as: Schaeffner B.C., Smit N.J. 2018: Parasites of cartilaginous fishes (Chondrichthyes) in South Africa - neglected field of marine science. Folia Parasitol. 66: 002. 